\title{
LA ELECCION O NOMBRAMIENTO Y CESE DEL ALCALDE: HISTORIA LEGISLATIVA REGIMEN ACTUAL
}

\author{
POR \\ ANTONIO MARTíNEZ MARÍN
}

\begin{abstract}
SUMARIO: EXPLICACIÓN PRELIMINAR. I. Período de 1812 a 1936: 1.1. 1812 a 1814 y 1820 a 1823: Elección popular del alcalde gaditano; 1.2. 1834 a 1836: Nombramiento gubernativo del alcalde de entre los tres vecinos elegidos censitariamente con mayor número de votos; 1.3. 1836-1845: La elección censitaria progresista versus nombramiento gubernativo moderado; 1.4. 1845-1854: Nombramiento gubernativo moderado del alcalde entre los concejales censitarios; 1.5 . 1854-1856: La elección y cese del alcalde como resultado de una síntesis entre las concepciones progresista y moderada; 1.6. 1856-1868: De nuevo el triunfo de la concepción moderada; 1.7. 1868-1875: La elección del alcalde por los concejales elegidos por los varones cabezas de familia mayores de veinticinco años; 1.8 . 1876-1923: Nombramiento gubernativo de los alcaldes de los ayuntamientos importantes entre los concejales moderados; 1.9. 1923-1930: Demagogia formal de la electividad democrática del alcalde; 1.10. 1930-1936: La fórmula democrática alternativa de la elección concejil o popular del alcalde. -lI. PERIODO DE 1936 A 1978: 2.1. El período bélico. Una larga década de Comisiones Gestoras; 2.2. El nombramiento y cese del alcalde franquista: 2.2.1. Nombramiento; 2.2.2. Cese; 2.2.3. El alcalde de los Ayuntamientos de Madrid y Bardelona. 2.3. Los intentos acomodaticios del régimen franquista a una sociedad de exigencias democráticas municipales; 2.4. Una interpretación del nombramiento y cese gubernativo del alcalde en el régimen franquista. III. LA ELECCIÓN Y CESE DEL ALCALDE EN EL SISTEMA VIGENTE: 3.1. Elección; 3.1. Elección; 3.2. Cese; 3.3. La destitución-elección del alcalde a través de la mociór de censura; 3.4. La disolución gubernativa del ayuntamiento como cese anormal del alcalde.-IV. CONSIDERACIONES FINALES
\end{abstract}

\section{EXPLICACION PRELIMINAR}

La recuperación del dato histórico legal y la regulación jurídica vigente de la elección o nombramiento gubernativo y cese del alcalde desde 1812 a 1936 (I), 1936-1978 (II) y 1978 hasta el momento actual (III) son el objetivo de estas páginas.

La exposición fundamentalmente dogmática -los propios textos normativos- intenta realizarse de modo dialéctico y lineal. El Diario de Sesiones de las Cortes con sus enconados debates y los mismos movimientos populares y golpes militares seudorrevolucionarios o reaccionarios facilitan el primero, mientras que el nacimiento, muerte y resurrección de los textos locales, al determinar sus períodos de vigencia, se convierten en el criterio cronológico 
delimitador de las referencias legales. El sistema franquista imposibilita, como régimen dictatorial, la dialéctica, tanto parlamentaria como doctrinal; no obstante, existen discrepancias y propuestas reformatorias del texto legal que demuestran como la tesisantítesis democrática en la elección y cese del alcalde no se silencia ni aun en este período.

Los puntos de partida de los que arranca este estudio son básicamente los siguientes: la cuestión municipal es capital para conocer nuestra historia. Marx escribe que la causa de que España sea tan mal conocida y juzgada en Europa reside en la sencilla razón de que los historiadores, en vez de descubrir su fuerza en su organización local, se han limitado a tomar sus materiales de los almanaques de la corte (1). El nombramiento y cese de los alcaldes ha sido la cuestión más enfrentada de la representatividad municipal en los debates parlamentarios y con una repercusión mayor -junto con la del derecho de sufragio- en la sociedad española. El cese del alcalde pretende mostrar el grado de intervención gubernativa en el principal cargo municipal y, por esta causa, la exposición prescinde de las causas y circunstancias genéricas que ponen fin al mandato, salvo las de la etapa gaditana y la actual. El dato jurídico es, además de su rigurosa certeza, la expresión misma de la mayoría detentadora del poder, ya electo ya espontáneo -popular o militar-. Finalmente, la posición del autor es democrática y por consiguiente la construcción se explica desde esa misma naturaleza de los materiales.

\section{PERIODO DE 1812 A 1936}

\subsection{2 a 1814 y 1820 a 1823: Elección popular del Alcalde gaditano}

Los primeros constituyentes institucionalizan un alcalde o alcaldes elegidos democráticamente por los vecinos del municipio a través del sufragio universal. La edad electoral es de veintiún años y la elegible de veinticinco. El procedimiento electoral es de segundo grado, y su regulación es muy incompleta, rudimentaria y simple e, incluso, el voto es público. Bastaría la constitucionalización democrática del alcalde para afirmar la ruptura y carácter revolucionario del primero de nuestros supremos textos. El antes y el después de la Constitución de 1812 fundamenta aún más el calificativo dado. .

(1) MARX, C., y Engels. F.: La revolución en España, Ariel, Barcelona, 1960, pp. 26-27. 
Destacados representantes de la política, del derecho y de las ciencias sociales, en general, han resaltado el magno alcance de la elección democrática de los representantes de la nación y del municipio y consiguientemente del primer alcalde constitucional español. Antonio Maura considera que la sustitución de los ayuntamientos integrados de regidores perpetuos, de regidores que habían comprado sus cargos, de delegados del poder real por otros electivos no fue corto empeño e, incluso, se atreve a afirmar este político conservador que upuede decirse que no se ocupó la Constitución de otra cosa» (2). No es en absoluto cierto que los primeros constituyentes se ocuparan sólo de la electividad democrática de los cargos concejiles y en concreto del más importante de todos ellos, pues la actividad popular, en segundo y tercer grado, se estableció con carácter general para las elecciones tanto de diputados a Cortes como municipales. Ahora bien, nuestra vida local, a comienzos del siglo XIX continúa teniendo -quizá por la debilidad de la vida estatal- una notable importancia, demostrada en la guerra de la Independencia, y la elección de las autoridades municipales es un arma, como así lo ha escrito Boquera, para destruir o desmontar una organización municipal perniciosa, pero arraigada por ser el producto de una evolución de siglos (3). Carlos Marx, tan crítico siempre con el sistema vigente, mantiene, como lo hacen otros autores ingleses y franceses, el carácter revolucionario así como la grandeza de la obra de las Cortes de Cádiz... «Desde el remoto rincón de la isla gaditana se lanzaron a la empresa de fundar una España nueva, tal como hicieron sus padres en las montañas de Covadonga y Sobrarbe» (4).

La elección vecinal del alcalde es una manifestación más del carácter democrático que se impone en los respectivos textos legales. La tenencia de unos ayuntamientos en los que se reúnan «la probidad, el interés y las luces» se conseguirá, para los valerosos constituyentes, con la elección libre y popular. Elegidos por los vecinos, según el diputado Toreno, los individuos del ayuntamiento "desempeñarán mejor su cargo y corresponderán a la confianza que los ha distinguido" (5).

La votación para el elegir al alcalde se realiza por la Junta de los Electores nombrados por los vecinos de las parroquias del municipio. Esta "conferencia» sobre las personas que puedan convenir

(2) Esta cita se encuentra en SIMÓN TOBALINA. J. L.: «El régimen local de la primera Restauración", Revista de Estudios de la Vida Local núm 198, 1978, p. 303.

(3) BOQUERA OLIVER, J. M.: «El sistema representativo municipal», Problemas Políticos de la Vida Local, 1965, p. 65.

(4) MARX, C., y ENGELS F.: La revolución... ob. cit., p. 116

(5) Diario de sesiones de las Cortes generales y extraordinarias núm. 464, sesión de 10 de enero de 1812, p. 1590. 
para el mejor gobierno del pueblo y elige por pluralidad absoluta de votos, o la mitad más uno de los electores, al alcalde o alcaldes, regidores y procurador o procuradores síndicos. La votación se hace de modo separado para cada uno de los cargos y se dispone expresamente que conste en acta el elector que vota y la persona a quien da su voto.

El carácter democrático de la representatividad municipal conlleva la ausencia de todo criterio basado en la riqueza o cultura para ser alcalde. Las causas de suspensión del ejercicio de los derechos del ciudadano y consiguientemente del elector son más bien excepcionales: incapacitados física o moral por interdicción judicial, deudores de los caudales públicos, sirvientes domésticos (6), aquéllos que no tienen empleo, oficio o modo de vivir conocido, y los procesados criminalmente. Para ser alcalde, además de no estar privado del ejercicio del derecho electoral, hay que tener, como se ha señalado, veinticinco años y cinco de vecindad y residencia en el pueblo. Además, se impide desempeñar el cargo a los empleados públicos de nombramiento real y a los eclesiásticos seculares, pues los constituyentes piensan que éstos deben dedicarse al desempeño de las sagradas funciones de su ministerio (7). Finalmente, el parentesco entre electores y elegibles se considera como causa de inelegibilidad en virtud de la Ley de parentescos no derogada. Como escribe Miguel Sánchez, «los electores no podían nombrar a sus hijos, padres, abuelos, yernos, primos, hijastros y cuñados viviendo las mujeres de éstos, ni parientes dentro del cuarto grado de consanguinidad y seguido de afinidad por computación civil y no canónica» (8).

El cargo de alcalde se pierde por fallecimiento, expiración del mandato, pérdida de la condición de elegible y por acumulación de mandato como diputado de las Cortes o de la diputación provincial (9). La autoridad estatal no interviene en la elección o nombramiento y cese del alcalde, y el criterio de esta primera etapa constitucional es, pues, el de la elección popular.

Fernando VII, por Real Cédula de 30 de julio de 1814, disuelve $y$ extingue los ayuntamientos constitucionales y establece los de 1808 en la planta y forma que entonces tenían, sin novedad ni

(6) El sentido que los constituyentes dan al término sirviente es el criado destinado al servicio sólo de la persona, a diferencia del dependiente, cuyos servicios no eran meramente personales. Véase Diario de Sesiones de las Cortes generales y extraordinarias núm. 342. sesión de 9 de septiembre de 1811, pp. 1804-1805.

(7) Constitución de Cádiz, artículo 25

(8) VizCAíno PÉREZ. V., y Miguel SÁnCHEZ, F. de P.: Guia de los alcaldes de los pueblos de España. Dirección de alcaldes constitucionales; Instituto de Estudios de Administración Local, Madrid, 1979, pp. 268-269. Orden de 19 de marzo de 1813 por la que se manda observar la ley sobre parentescos en la elección de individuos para los ayuntamientos.

(9) Decreto de 11 de agosto de 1813, regla tercera. 
alteración alguna en cuanto a la denominación, número, calidades y funciones de los oficios y empleados de que entonces contaban. El absolutismo tomaba su revancha contra el liberalismo democrático gaditano mediante un golpe militar, en este caso el del general Eguía. Como recuerda Tuñón de Lara, el absolutismo integral y la reacción intransigente reinaron desde aquel día. Calatrava y García Herreros fueron condenados a ocho años de presidio en Melilla y Alhucemas, respectivamente; Argüelles, a otro tanto en El Fijo, de Ceuta; Muñoz Torrero, a seis años de reclusión en el monasterio de Ermon (Galicia); Martínez de la Rosa, a ocho años en el Peñón... (10).

A pesar de esta decapitación liberal, España no se somete sumisamente al régimen absolutista fernandino, y los militares liberales creen que con un golpe de audacia podía ser vencido éste. Tras varios pronunciamientos militares antiabsolutistas fracasados, el general Riego proclama la Constitución de 1812 en Cabezas de San Juan el día 1 de enero de 1820.

Entre las disposiciones locales del trienio y en la medida que altera el principio constitucional de la libre elección de los ayuntamientos sin intervención gubernativa estatal alguna, debe mencionarse el Decreto de 1 de noviembre de 1822: el Gobierno es autorizado para que, oyendo a las diputaciones provinciales y a los jefes políticos, pueda suspender a los miembros de los ayuntamientos, reemplazándolos con otros individuos que lo hayan sido de ellos en los años anteriores después de establecida la Constitución.

La excepcionalidad de esta medida, explicable por la situación políticamente inestable y enfrentada que vive el país, supone, no obstante, una quiebra del principio de la voluntad popular constitucionalizado. Once meses después, el Real Decreto de 1 de octubre de 1823 declara nulos y sin valor ni efecto todos los actos del Gobierno constitucional. El absolutismo volvía a imponerse, aunque en esta ocasión con la ayuda de los Cien Mil Hijos de San Luis.

Una pregunta debe ser formulada ante esta regulación legal revolucionaria del alcalde elegido por sufragio universal masculino en 1812. ¿Los constituyentes representaban a toda la sociedad española? La respuesta es negativa, pues los primeros padres de la patria de la historia constitucional procedian de los sectores más patrióticos, valerosos y progresistas en su mayoría y, desde luego, hicieron Derecho en unas circunstancias bélicas y sociológicas determinantes. De nuevo Marx ha sido clarividente en esta cuestión al enunciar las circunstancias favorables que permitieron la reunión en Cádiz de los hombres más progresistas de España: las eleccio-

(10) TUÑón DE LARA, M.: La España del siglo XIX, tomo I, undécima edición, Laia, Barcelona, 1977, p. 53. 
nes se hacen en un momento revolucionario, y la antipatía a la Junta Central favorece el éxito de sus antagonistas. Los representantes proceden de las provincias más democráticas, pues de las del interior, más reaccionarias, apenas fueron por no haber podido realizar elecciones. Los representantes americanos son más bien personas innovadoras, pues ante la tardanza que la elección y el desplazamiento suponían se habían nombrado como diputados suplementarios a personas que en ese momento están en la península $y$, sobre todo, en Cádiz. Finalmente, ésta es la ciudad más radical del reino y la población presiona e intimida, incluso a los "reaccionarios», cuando sus opiniones se hacen imperiosas (11). Las Españas afrancesada, cobarde, indiferente y absolutista no están representadas, y los diputados liberales poseian una juventud y una confianza, propia de la época, en que la realidad debía y podía ajustarse a la razón jurídica.

\subsection{4 a 1836: Nombramiento gubernativo del Alcalde de entre los tres vecinos elegidos censitariamente con mayor número de votos}

Si el antiguo régimen muere con Fernando VII, es básicamente una coincidencia, pues la sociedad del siglo XIX es quien ya no soporta sus principios y valores sobre los que durante los últimos siglos se había fundado. ¿Cómo se regula la institución del alcalde? ¿Quién le va a nombrar y cesar? ¿A quién va a representar? ¿Qué rátio política explica y justifica la regulación jurídica dada?

El Estatuto Real de 18 de junio de 1834, auténtica carta otorgada, silencia de modo absoluto cualquier referencia municipal. Al amparo de éste, que como ha señalado Tomás Villarroya, identifica la nación legal con la de los propietarios (12), se publica el Real Decreto de 25 de julio de 1835, verdadera ley orgánica de los ayuntamientos en expresión de Posada (13).

Una primera disposición genérica define el sistema políticoadministrativo del Real Decreto mencionado. En el supuesto de que la mayoría de los electores se abstuviesen de votar, el gobernador civil, oyendo a la diputación provincial, nombrará a los individuos del ayuntamiento, escogiéndolos entre los vecinos elegibles, sin oír en contra de ello quejas ni reclamaciones algunas. Incluso en el supuesto de elegibles que no hubiesen obtenido la mayoría abso-

(11) MARX C., y ENGELS F.: La revolución en España, ob. cit., pp. 129-130.

(12) TOMÁS VILLARROYA J.: El sistema político del Estatuto Real (1834-1836); Instituto de Estudios Politicos, Madrid, 1968, p. 129

(13) POSADA, A.: Evolución legislativa del régimen local en España, 1812-1909, Madrid, 1911, p. 117. El Instituto de Estudios de Administración Local ha publicado en 1982 una segunda edición. 
luta, es el mismo gobernador civil quien, de una lista doble numéricamente en relación con las vacantes de aquellos que han obtenido mayoría, nombrará a los individuos para los cargos vacantes (14).

El gobernador civil nombra al alcalde entre los tres elegidos con mayor número de votos $\mathrm{y}$, facultativamente, a los tenientes de alcalde de entre los demás. En los pueblos de mayor importancia -a partir de 2.000 vecinos- es el Rey quien nombra al alcalde de la terna mencionada. Este criterio es mantenido, con determinadas variantes y salvo algunas excepciones, en la historia de la representatividad municipal española: el Gobierno central nombrará a los alcaldes de los pueblos de mayor importancia, y el resto se dejará en manos de su agente periférico provincial.

El dependentismo gubernamental de los ayuntamientos se completa con la facultad que el Gobierno central se atribuye de suspender y destituir a las autoridades municipales. Sin señalar criterio alguno de oportunidad o de legalidad, el gobernador civil puede suspenderlas, $y$ el Gobierno central -S. M.- destituirlas. En el supuesto de que por muerte, imposibilidad física o por cualquier otro motivo vacare alguno de los oficios del ayuntamiento, el gobernador civil nombra un sustituto hasta la nueva elección entre los que hubiesen servido tal cargo en el año anterior (15).

Un dato de capital importancia configura la elección y cese estatal del alcalde. Los electores deben tener veinticinco años cumplidos y, sobre todo, ser contribuyentes y disponer de medios económicos suficientes que produzcan a su dueño una subsistencia independiente. Dos requisitos altamente restrictivos limitan aún más el número de vecinos que pueden ser alcaldes: saber leer y escribir y encontrarse en la décima parte de electores que sean mayores contribuyentes. En una sociedad analfabeta y de propiedad concentrada, la electividad es rigurosamente oligárquica..Junto a la destitución gubernativa del alcalde, el nuevo texto local posibilita sólo un segundo mandato continuado, pues para después de la primera renovación -a finales de 1836- será necesario dejar un hueco de una elección a otra.

En 1835, como acertadamente ha señalado García Fernández, ya se ha descubierto en España que el modelo centralizador napoleónico podía utilizarse para consolidar el poder oligárquico (16).

(14) Real Decreto de 1835, arts. 26 y 27

(15) Ibidem, arts. 9 y 10

(16) GARCí FERNÁNDEZ. J.: El origen del municipio constitucional; Instituto de Estudios de Administración Local, Madrid, 1983, p. 314. MORILLO VELARDE, igualmente, considera a este Real Decreto como una importación de las técnicas de organización francesa. MORILLO VELARDE. J. L.: El Alcalde en la Administración española, Instituto "Garcia Oviedo», Sevilla, 1977, p. 58. 


\subsection{6 a 1845: Elección censitaria progresista versus nombramiento gubernativo moderado}

El motín de La Granja no es un pronunciamiento aislado de las clases de tropa, sino una acción culminadora de un movimiento popular que había sacudido ya las principales ciudades, y responde, como Marichal ha escrito, a una verdadera revolución nacional que marcó el fin de la etapa más crítica de la transición de la monarquía absoluta al Estado liberal y parlamentario (17). Los Reales Decretos de 13 de agosto y 15 de octubre de 1836 restablecen la Constitución de 1812 y la Ley de 3 de febrero de 1823, relativa al Gobierno Económico-Político de las Provincias. De nuevo vigente el régimen gaditano, las nuevas Cortes se proponen como tarea elaborar un nuevo texto constitucional y una nueva ley para los ayuntamientos. El primer objetivo se logra con la Constitución de 18 de junio de 1837; sin embargo, el segundo, sólo se alcanzará con la Ley de 14 de julio de 1840 -suspendida por Decreto de la

-'Regencia de 13 de octubre de 1840 y puesta en ejecución de nuevo por Real Decreto de 31 de diciembre de 1843-, aunque modificada en algunos de sus artículos para que las autoridades municipales fueran enteramente de elección vecinal. La legislación gaditana está vigente desde agosto-octubre de 1836 hasta el último día de 1843, salvo el período turbulento de los tres meses referidos de 1840 .

Los historiadores coinciden en agrupar a los políticos del decenio 1834-1844 en los partidos moderado y radical o progresista. Como es obvio, no son partidos de masas, sino esencialmente oligárquicos, y buscan afianzar su poder y promover los intereses de los grupos restringidos que representan. Los moderados son los oligarcas del liberalismo, mientras que los progresistas, partido más heterogéneo socialmente, se integraban en mayor medida en las clases medias y en cierta burguesía de las ciudades más desarrolladas y contaban con la simpatía y apoyo del pueblo (18).

Los progresistas gobiernan durante 1836 y 1840-43, y los moderados el resto del período. Mientas los primeros detentan el poder no sólo no hay nueva ley local sino ni siquiera proyecto alguno presentado a las Cortes. La causa determinante de esta pasividad no es otra que la del oportunismo político, pues la legislación gaditana les facilita o proporciona la tenencia de los

(17) MARICHAL, C.: La revolución liberal y los primeros partidos políticos en España, 1834-1844, Cátedra, Madrid, 1980, p. 130.

(18) Véase MARICHAL C.: La revolución..., ob. cit., pp. 132-134 y 169. TUÑÓN DE LARA M.: La España..., ob. cit., pp. 128-130. CARR R.: España 1808-1975, Ariel, Barcelona, 1969. pp. 163 y 170-171. 
ayuntamientos. Contrariamente, los moderados necesitan para conquistar el poder municipal un nuevo y diferenciado texto local. Los Proyectos de las legislaturas de 1838, 1839 y 1840 , posteriormente la Ley del mismo año, son manifestaciones inequívocas del deseo moderado de sustituir el régimen local de la primera Constitución.

La Administración local actúa, como ha escrito Concepción de Castro, como catalizador de todas las divergencias de los dos partidos burgueses en 1840 (19). Y la gran cuestión que les enfrenta frontal e irreconciliablemente es el de la elección y cese del alcalde. Hay también otra disconformidad en relación al derecho de sufragio vecinal, pues, como puntualiza Sosa Wagner, los progresistas amplían el voto hasta la clase media mientras que para los moderados es más reducido (20). Definitivamente la diferencia entre ambas formaciones políticas radica en el quantum económico, pues los políticos de uno y otro bando han renunciado al sufragio universal y consideran que «la capacidad electoral debe estar proporcionada con la riqueza y la industria». Argüelles, en este sentido, confiesa que él «nunca ha sido partidario del sufragio universal, pero considera que no se debe excluir a tanto vecino honrado" (21). Sancho, tras confesarse liberal progresista $y$ monárquico, reconoce que sería antimonárquico y anticonstitucional si aprobase el sufragio universal, y Roca de Togores generaliza que «todos somos muy enemigos del sufragio unirvesal» (22).

El gran debate parlamentario de la Ley de 1840 no es otro que el de si el poder central debe designar a los alcaldes o son los electores quienes exclusivamente han de elegirlos. La cuestión no es baladí, pues en el triunfo de una u otra opción estaba en juego un modelo de Estado monocéntrico centralizado o descentralizado. Los progresistas rechazaban la intervención gubernativa y los moderados no soportaban unos ayuntamientos libres. Los razonamientos de unos y otros durante las legislaturas de 1837-38 y 1840, pues la de 1839 fue tan breve que imposibilitó el debate del Proyecto de ley presentado, fundamentarán ya para el futuro ambas posiciones irreductibles.

La defensa moderada de la designación gubernativa de los alcaldes y tenientes de alcalde se apoya principalmente en las argumentaciones siguientes:

(19) CASTRO, C. DE: La revolución liberal y los municipios españoles, Alianza, Madrid, 1979 , p. 166.

(20) Sosa WARnER. F.: Manual de Derecho local, Tecnos, Madrid, p. 38.

(21) Diario de Sesiones del Congreso, legislatura de 1837-38, sesión de 19 de abril de 1938, p. 1820 .

(22) Ibídem, legislatura de 1840, sesión de 11 de abril de 1840, pp. 964 y 968. 
Una concepción centralista del poder público en el que «el ayuntamiento es el último eslabón de la cadena administrativa.... y la consiguiente necesidad de la unión y dependencia en esta máquina administrativa». Con la legislación gaditana «jamás se está tan cerca de que se rompa esa unión y se introduzca la anarquía», de ahí que el Gobierno, reitera Martínez de la Rosa, debe tener «influjo» en los agentes de los ayuntamientos a fin de que la acción llegue desde el trono hata la última aldea del reino (23).

Una segunda argumentación justificativa de este intervencionismo es la confluencia en el municipio de intereses particulares y de intereses generales... y el alcalde y tenientes de alcalde, en la medida que eran ejecutores de las disposiciones del Gobierno, debían contar con su confianza. El Gobierno de los pueblos, dado este doble carácter, es elegido por los electores y la corona designa de entre éstos a los que tienen autoridad de ejecución (24).

La argumentación del modelo extranjero fundamenta también la opción moderada. Martínez de la Rosa y Oliván, presidente de la Coḿnisión en la legislatura de 1840, alaban el módelo centralista francés, incluso este último lo justifica especialmente al afirmar que «si nosotros tuviéramos instituciones municipales antiguas que copiar de nuestro país, creo que sin vacilar las desenterraríamos y restableceríamos con aplausos; pero por desgracia no las hay" (25).

La oposición progresista a la intervención gubernativa en la designación de los alcaldes y tenientes de alcalde y en la actividad de los ayuntamientos es mucho más rica y fundada.

Una concepción descentralizada del poder público a nivel municipal, pues la centralización, dirá Luján, «llevada más adelante que conviene es "acumular sangre en la cabeza, produciendo una apoplejía del Gobierno, y dejando los demás miembros paralíticos"'» (26). En España la centralización es un sinsentido tanto topográfico como bélico y el peso de Madrid sobre el resto del país no la posibilita, como sucede con París sobre Francia. Además, dirá el gran Argüelles, «¿puede el Gobierno del día, ni los anteriores, señalar obstáculos ni embarazos que se hayan opuesto a la marcha del Gobierno desde el año de 1834 por los Ayuntamientos de la Península? Seguro estoy de que no me los señalen..., yo he visto

(23) Véase el Diario de Sesiones del Congreso, legislatura de 1837-38, sesión de febrero de 1838 , pp. 777-778, sesión de 20 de abril de 1838, p. 1839.

(24) Ibidem, legislatura de 1837-38, p. 778; legislatura de 1840, sesión de 14 de abril, página 1022 .

(25) Ibídem, legislatura de 1840, sesión de 20 de abril, p. 1087; sesión de 21 de mayo. pp. 1812 y ss

(26) Ibidem, legislatura de 1838, sesión de 17 de abril de 1838, p. 1767. 
con la mayor atención el proyecto del Gobierno, y nada he hallado que manifieste la necesidạd de esas alteraciones, que parecen más bien del prurito de innovar, de asemejarnos a la nación vecina y de desnaturalizar nuestras instituciones» (27).

La razón cognoscitiva como base de una mejor elección aconseja que sean los vecinos quienes nombren a su alcalde. Los vecinos son quienes mejor que nadie conocen las cualidades del futuro alcalde, pues ellos le han visto nacer, crecer... El Gobierno y el jefe político carecen de ese conocimiento vecinal y consiguientemente habrán de valerse de los informes confidenciales de algunas personas. Entre la elección vecinal y el informe confidencial para nombrar al alcalde debe preferirse el primero. Se argumenta también, en este sentido, que en cuanto el proyecto de ley sólo confía al electorado la elección de los regidores es posible que el regidor más votado no sea el querido por los votantes para alcalde o, como una contradicción más, si el Gobierno o jefe político no nombra para alcalde a este, ¿«quién es el guapo, por decirlo así, que vaya a ser alcalde sin ser nombrado por el pueblon? Con el sistema propuesto de designación gubernativa, «los alcaldes podrían mirarse como unos esbirros del Gobierno y se desacreditaría esta noble institución» (28).

Junto al rechazo de la referencia modélica francesa de los moderados - «en Francia se descentraliza y aquí se centraliza. Se imita a un país que no tiene Administración municipal y que envidia la nuestra»-, los progresistas apoyan su sistema descentralizador en otro ejemplo extranjero, al que consideran superior en esta materia: Inglaterra. Hay en esta primera mitad del siglo XIX una conexión relativa de los moderados con Francia y de los progresistas con Inglaterra. Los primeros suelen exiliarse en el país vecino y a su vuelta predican las virtudes del modelo centralista francés, que hasta la III República nombra a sus alcaldes por el Gobierno central y el prefecto (María Cristina, Javier de Burgos, Oliván, Martínez de la Rosa, Toreno, Narváez, etc.). Los progresistas se exilian en Inglaterra, donde la Corona no se interfiere en el nombramiento de las autoridades locales (Espartero, Argüelles, Mendizábal, Calatrava, etc.). "La Reina de Inglaterra, afirmará Argüelles, hoy joyen inexperta, que acaba de subir al trono, sorprende cómo es acatâda por un magistrado en cuyo nombramiento ninguna intervención tiene el Gobierno... ¿quién ha dicho en Europa que el Gobierno de España monárquico-constitucional no se crea en disposición de

(27) Ibidem, sesión de 4 de abril de 1838, pp. 1765 y ss. También sesión de 19 de abril de 1838 , p. 1818

(28) Ibidem, sesión de 19 de abril de 1838, pp. 1812 y ss., especialmente la página 1819 Sesión de 13 de abril de 1840, pp. 968 y ss. 
conservar el orden, la tranquilidad pública y de hacerse respetar porque los alcaldes sean nombrados como lo son hoy en día?» (29).

La razón jurídica fue el principal argumento sostenedor del rechazo progresista al nombramiento gubernativo de los alcaldes y tenientes de alcalde, la causa de la suspensión de la Ley de 1840 y de la derogación de los artículos reguladores de la mencionada designación cuando tres años después se ponía de nuevo el texto en vigor. El artículo 70 de la Constitución de 1837 establecía que «para el gobierno interior de los pueblos habrá ayuntamientos nombrados por los vecinos, a quienes la ley concede este derecho». "Habrá, pues, Ayuntamientos nombrados por los pueblos y el alcalde es miembro de aquéllos $y$, por consiguiente, debe ser nombrado por los pueblos» dirá Luján $(30)$, incluso «no hay nadie que no sepa que la principal parte del ayuntamiento es el alcalde», insistirá Olózaga. «El artículo 70 de la Constitución de 1837 es, desprovisto de su carácter reglamentario, el 312 de la Constitución de Cádiz... y ni un solo diputado dijo que se alterara el espíritu, la tendencia de lo que la Constitución de 1812 prescribía respecto de las corporaciones populares...» (31). Esta ley, concluirá Argüelles, no sólo está en abierta contradicción con la Constitución, sino que es un golpe directo contra ella, pues ataca el artículo 70 y, además, es el precursor de otros ataques que indudablemente llegarán aquí si desde el principio no les oponemos obstáculos» (32).

Dado que la mayoría de los diputados era moderada, triunfó su opción, a pesar de que la razón era progresista.

El Rey, por el Ministerio de la Gobernación, y previo informe de los jefes políticos, elige al alcalde y a los tenientes de alcalde de todas las capitales de provincia de entre los regidores del ayuntamiento. El jefe político de cada provincia lo hace, en los mismos términos que el Rey, en los pueblos cabeza de partido o que sobrepasen los 500 vecinos (33).

El Gobierno no necesita, como en 1835, limitarse para la designación del alcalde a los tres individuos más votados, sino que su discrecionalidad es absoluta. Incluso la designación de los tenientes de alcalde con idéntico criterio discrecional acentúa aún más la decisión gubernamental en la voluntad municipal. El Gobierno renuncia a su intervención en los municipios más pequeños en razón de que en éstos hay menos intereses, menos puntos

(29) Ibidem, sesión de 12 de mayo de 1840, pp. 1603 y ss.

(30) Ibidem, sesión de 17 de abril de 1838, p. 1771

(31) Ibidem, sesión de 13 de abril de 1840, pp. 989 y 1012

(32) Ibídem, sesión de 12 de mayo de 1840, p. 1605

(33) Ley de 14 de julio de 1840, art 45 
de contacto con el interés general, son más fáciles de gobernar y hay menos resistencia y obstáculos al poder central (34).

La interverición gubernativa en la suspensión y destitución de los individuos del ayuntamiento como en la disolución de éste se mantiene expresamente en este texto legal: el jefe político puede suspender a un ayuntamiento y el Rey disolverlo, así como destituir al alcalde o tenientes de alcalde. La decisión gubernativa es enteramente de oportunidad, pues aun en el supuesto de infracción legal la autoridad central sólo pasará noticia a los Tribunales si lo creyere necesario (35).

La historia jurídica de España no se ha hecho sólo en el Parlamento, sino también, en la calle. Tomada como bandera la anticonstitucionalidad del nombramiento gubernativo de los alcaldes y tenientes de alcalde, un buen número de ciudades con ayuntamientos progresistas se manifiesta contra el Gobierno central. María Cristina sanciona el texto el 14 de julio. Espartero, sintonizando el clamor popular, pide a la soberana la derogación de la Ley a causa de su quebranto constitucional. La población y el partido progresista entregan su causa al general, involucrando al Ejército en la vida política. La Regente, negándose a presidir un gabinete progresista, abdica oficialmente el 12 de octubre $y$, considerada como la mujer más rica de Europa, en expresión de Marichal (88), se marcha a Marsella. El Decreto de 13 de octubre de 1840 suspende la ejecución de la Ley de 1840, pues «en ella se ha infringido el artículo 70 de la Constitución del Estado; y esto bastaría para que se negase a que bajo su responsabilidad se pusiese en práctica; tal es el respeto y reverencia que la ley fundamental del Estado le merece.....

Durante la regencia de Espartero se presenta, anómalamente, un Proyecto de Ley sobre Organización y Atribución de los Ayuntamientos al Senado en la sesión de 13 de marzo de 1842, pero su discusión queda suspendida y retirado del Senado en 1843 no pasó, obviamente, al Congreso. El texto consagra el principio electivo en coherencia constitucional y de no haberse producido la ruptura de los progresistas con Espartero el texto presumiblemente se hubiera convertido en ley. En este sentido, el Proyecto de Ley Electoral de Ayuntamientos, presentado por el Gobierno Olózaga, es aprobado en diciembre de 1843 en el Senado, pero, remitido al Congreso, no llega a ser discutido a causa de la caída del Gabinete.

Finalmente, de nuevo los moderados en el poder, se pone de nuevo en vigor la Ley de 1840 por Real Decreto de 30 de diciembre de 1843, pero sustituyendo la designación gubernativa de los

(34) Diario de Sesiones del Congreso, sesión de 21 de mayo de 1840, p. 1840.

(35) Ley de 14 de julio de 1840, arts. 57 y 58 
alcaldes por la elección directa: "será alcalde el que reúna mayor número de votos; teniende o tenientes, los que sigan con más votos, y los restantes, regidores" (36). La exigencia constitucional estaba cumplida, pero el pensamiento moderado municipal permanecía inalterable y muy pronto tuvieron oportunidad de demostrarlo.

\subsection{5 a 1854: Nombramiento gubernativo moderado del alcalde entre los concejales censitarios}

La ruptura esperada y justificada de la relación contra natura de Espartero con los progresistas, la división de éstos, víctimas de sus propias contradicciones, y la persecución moderada contra los sectores populares y progresistas más radicales son algunas de las causas del triunfo aplastante de los moderados en las Cortes de 1844-45. Concepción de Castro resalta el dato significativo de esta desaparición de la escena política: en las mencionadas Cortes la oposición progresista se reduce a un solo diputado (37).

La Ley de los Ayuntamientos de 8 de enero de 1845 es un texto netamente moderado y muestra de manera inequívoca su pensamiento reaccionario, tanto en la subordinación de las autoridades municipales al Gobierno central como en su representatividad económicamente oligárquica. La Constitución de 23 de mayo de 1845, adaptándose a lo establecido en el texto municipal, dispone en su artículo 73 que: "Habrá en los pueblos alcaldes y ayuntamientos. Los ayuntamientos serán nombrados por los vecinos a quines la ley les confiera este derecho.» El supremo texto ya no será obstáculo jurídico para el nombramiento gubernativo de la máxima autoridad municipal.

Los alcaldes y tenientes de alcalde son nombrados por el Rey en todos los ayuntamientos de las capitales de provincia y en los de las cabezas de partido judicial cuya población llegue a 2.000 vecinos. En los demás pueblos los nombra el jefe político por delegación del Rey. En ambos casos, el nombramiento se hace entre los concejales electos (37). De êste modo breve, claro pero absolutamenta irracional, a causa de la imposibilidad cognoscitiva del Gobierno y del jefe político de las miles de personas nombradas, se positivizaba el sistema que el moderado Oliván consideraba preferible a todas luces (38).

(36) Nuevo artículo 45 de la Ley de 1840.

(37) Ley de 8 de enero de 1845, art. 9

(38) OLIVÁN, A.: De la Administración pública con relación a España, Instituto de Estudios Politicos, Madrid, 1954, pp. 153-154. El razonamiento justificativo del nombramiento de los alcaldes por la Corona se encuentra correctamente expuesto en POSADA HERRERA, J.: Lecciones de Administración. I, Madrid, 1843, pp. 380-381 
La facultad de suspender individual o colectivamente al alcalde y a los demás miembros del ayuntamiento, dando cuenta al Gobierno, la tiene atribuida el jefe político. La de la destitución y disolución del ayuntamiento corresponde al Gobierno (39).

El intervencionismo gubernativo todavía se intensifica más. El artículo 10 de la Ley de Ayuntamientos dipone que: «El Rey podrá nombrar libremente un alcalde corregidor en lugar del ordinario en las poblaciones donde lo conceptúe conveniente. La duración será ilimitada y el cargo retribuido.» Incluso, como recuerda Morell Ocaña, los jefes políticos subalternos de distrito o jefes civiles, donde los hubiere, serían, en virtud del artículo 1 del Real Decreto de 1 de diciembre de 1947, alcaldes-corregidores en los pueblos de su residencia (40). Los fragmentos citados fundamentan la afirmación de Adolfo Posada: "Las leyes de 8 de enero expresan el criterio centralizador, de dependencia jerárquica y de desconfianza más puro» (41).

El alcalde modeado de la Ley de 1845 es un regidor nombrado gubernativamente. Pero el derecho de sufragio, tanto activo como pasivo, es mucho más restrictivo que el de 1840 . Si, como en este texto, es necesario ser cabeza de familia mayor de veinticinco años para ser elector, los límites numéricos máximos, para poder emitir el voto y sobre todo para ser elegible, son tan bajos que la representatividad municipal sólo lo es de los mayores contribuyentes, de la reducida oligarquía económica. Ejemplíficamente, en los pueblos de 20.000 vecinos votan sólo los 1.767 mayores contribuyentes y el número de elegibles se reduce a la mitad (42).

\subsection{4-1856: La elección y cese del alcalde como resul- tado de una síntesis entre las concepciones progresista y moderada}

Vicálvaro es un pronunciamiento de los militares acompañado de revueltas populares en algunas ciudades importantes contra la corrupción gubernamental existente. El mismo Cánovas del Castillo dirá en las nuevas Cortes que... «Las leyes de 1845 eran sólo una máquina para ganar elecciones..." y concluye atribuyéndose incluso la paternidad del cambio: «nosotros somos los autores de la revolución de junio y julio» (43). Espartero y O’Donnell conniven en

(39) Ley de 8 de enero de 1845, arts. 67 y 68.

(40) MORELl OCAÑA. L.: "La figura del alcalde, desde la Constitución de Cádiz hasta el canovismo», en Revista Española de Derecho Administrativo núm. 33, 1982, p. 176.

(41) POSADA A.: Ob. cit., p. 157.

(42) Ley de 8 de enero de 1845 , arts. 13 y 20.

(43) Diario de sesiones de! Congreso, legislatura de 1854-1856, sesión de 14 de diciembre de 1854, pp. 638-639 
el Gobierno hasta que este último, dos años más tarde, como significa Artola, se convierte en el restaurador del régimen que destruyera antes (44).

Si se tiene en cuenta que en el Gobierno del bienio están juntos los moderados y los progresistas menos puros comandados por los militares O'Donnnel y Espartero no sorprende ni la brevedad de este período; ni la ausencia de frutos jurídicos, Constitución. nonnata y la Ley de Ayuntamientos apenas vigente de 5 de julio de 1856; ni la ausencia de auténticas elecciones municipales durante el período. La vigencia de la Ley de 1823 y demás disposiciones vigentes a la publicación del Real Decreto de 30 de diciembre de 1843 limita su alcance electoral sólo a aquellos ayuntamientos que no habían celebrado comicios por orden de las juntas o diputaciones provinciales. El Gobierno no realiza elecciones municipales generales. El 14 de julio de 1856 O'Donnnell se hace con el poder, disuelve las Cortes por Real Decreto de 2 de septiembre de 1856 y por el de 16 de octubre del mismo año restablece la legislación local de 1845.

El alcalde de la Ley de 1856 es una síntesis del pensamiento moderado y progresista. En la elección y cese se ponen de manifiesto las reciprocas concesiones y el mantenimiento de la concepción burguesa del derecho de sufragio, tanto activo como pasivo, de ambos.

Los electores eligen a su alcalde primero o único a través del voto secreto y directo de entre los vecinos elegibles. Aquel que obtenga la mayoría de votos resulta electo.

La Ley de 1856 se aparta del pensamiento progresista en el intervencionismo gubernativo posibilitado en el artículo 242: "Cuando un ayuntamiento, alcalde o alcaldes, regidor o regidores, incurren en hechos $u$ omisiones punibles administrativamente, pueden ser, según los casos, amonestados, apercibidos, multados o suspendidos por sus superiores jerárquicos». Ciertamente, la suspensión se encuentra reglada tanto en cuanto a las causas -alteración del orden público y desobediencia grave-, procedimiento -en el primer supuesto suspende el gobernador civil después de haber oído a la diputación y en el segundo se exige el acuerdo común de estos dos órganos, aunque si éste no existiera se eleva al Gobierno para que decida con el informe del Consejo de Estado- y temporalidad -el período de suspensión no podrá exceder de treinta días-. Si el Gobierno considera que procede la formación de causa o la disolución remite los informes al tribunal que corresponda, en el primer supuesto, o un Proyecto de Ley de

(44) ARTOLA, M.: Partidos y programas politicos, Aguilar, Madrid, 1974, p. 261. 
disolución a laş Cortes para que éstas decidan al respecto (45). La destitución corresponde al tribunal de primera instancia y la disolución a las Cortes.

La facultad suspensiva atribuida al gobernador civil es denunciada, como era presumible, por el pensamiento progresista más puro o fiel al principio excluyente de cualquier intervención gubernativa en la representatividad municipal. Tanto en la discusión de la Ley de bases como en la de la Ley articulada hay un reproche inequívoco hacia la facultad suspensiva legislada: «¿Sabéis que establecéis una medida que no hará más que complicar la máquina, destruís en su esencia el carácter y la naturaleza del municipio progresista?... rompéis la armonía que debe haber entre corporaciones que deben su origen a la elección popular; sustituís, en fin, esto a lo dispuesto por las Cortes en 1812, en 1823, intrusando al Gobierno central en el núcleo del municipio, que tanto dista de él». "Esta ley es malísima, porque entrega a los ayuntamientos atados de pies y manos a la influencia del gobernador... por este artículo constituiremos la autoridad de los ayuntamientos en débiles instrumentos del gobierno") (46).

El sufragio universal continúa siendo rechazado y los criterios electorales positivizados son el sexo, riqueza, edad y estado civil: votan los varones mayores contribuyentes de edad superior a los veinticinco años y siempre que sean cabezas de familia. Obviamente, si el partido progresista había carecido de un pensamiento unánime coincidente en esta materia, ahora, al final ya de su existencia política, también se encuentran voces que continúan proclamando su fidelidad al sufragio universal y a su concepción democrática municipal... y que merecen ser mencionadas: el marqués de Albaida pide el sufragio universal directo para la nueva Ley progresista por considerar que la elección directa es mejor que la indirecta. Castro, incluso, pone en entredicho el sello progresista de la Ley: "puesto que sois progresistas, ¿por qué no establecéis el sufragio universal?» Francisco Salmerón, autodenominándose progresista puro, rechaza la Ley por su carácter censitario y la considera injusta y antiprogresista en cuanto se separa del sufragio universal de la primera etapa constitucional. De igual modo, Arriaga denuncia que bajo bandera progresista se mantengan principios moderados, de la escuela doctrinaria (47).

(45) Ley de 5 de julio de 1856, arts. 238-252

(46) Diario de Sesiones del Congreso, legislatura de 1854-1856, sesión de 6 de marzo de 1856, p. 11366 y sesión de 23 de junio del mismo año, p. 14498.

(47) Ibidem, sesión de 14 de diciembre de 1854, pp. 631-633; sesión de 6 de marzo de 1856, pp. 11364 y 11400 , y sesión de 10 de marzo de 1856, p. 11510. 


\subsection{6-1868: De nuevo el triunfo de la competencia moderada}

El consenso del bienio se rompe en favor del pensamiento moderado. De nuevo se restablece la Constitución y la Ley de Ayuntamientos de 1845. No obstante, el Acta adicional muestra el alcance de la ligera diferencia entre los moderados de Narváez y los unionistas de O'Donnell: el Rey ya no podrá nombrar libremente a los alcaldes-corregidores de cualquier municipio, como se establecía en el texto moderado; sin embargo la facultad se mantiene para los municipios de 40.000 almas en adelante. Esta medida reductora de la libertad gubernativa del nombramiento del alcalde a las ciudades de mayor peso demográfico apenas tiene vigencia, porque, de nuevo, Narváez vuelve, deroga el Acta Adicional y restablece enteramente los textos de 1845.

Esta segunda etapa moderada ofrece, además del restablecimiento de la legislación mencionada, una restricción todavía mayor de la base elegible positivada en 1845 y dos Proyectos de Ley sobre organización y atribuciones de los ayuntamientos. El Real Decreto de 21 de octubre de 1866, obra de Narváez-González Bravo, reduce aún más las cifras de mayores contribuyentes a los que se les concede el derecho de sufragio pasivo. Los otros dos textos son obra de O'Donnell-Posada Herrera y significativamente difieren entre sí. El de 1860 se alinea en la posición moderada de la Ley de 1845 y el de 1866 en la de 1856. La posición política fortalecida del unionismo en la primera fecha no obliga a concesión alguna para con los progresistas y demócratas, mientras que la situación ha cambiado en marzo de 1866: el unionismo debilitado pretende atraer por última vez a aquéllos con un texto que viene a ser una imitación de la Ley de 1856. El intento resulta fallido, pues en julio del mismo año a O'Donnell se le retira la confianza regia y la corona llama de nuevo a los moderados puros con su jefe Narváez. Estos serán los únicos que la defenderán... mientras los progresistas y demócratas, a los que se le han unido los unionistas, preparan la caída de la Reina y de la dinastía misma.

\subsection{8-1875: La elección del alcalde por los concejales elegidos por los varones cabezas de familia mayores de veinticinco años}

La inestabilidad política de esta época se manifiesta en una revolución (1868), un período de inexistencia de un régimen político determinado (1868-69), una monarquía sin Rey (1869-1870), una monarquía con Rey (1870-1873), una república (1873-1874), un nuevo período de incertidumbre (1874) y finalmente la restauración 
del régimen monárquico con Alfonso XII (1875...). Obviamente, la preocupación y consiguiente problema más importante para el país es la institucionalización de un régimen político determinado; sin embargo, la cuestión municipal continúa estando presente y regulándose en consonancia con las fuerzas políticas en el Gobierno... en la medida que éstas dispongan del tiempo suficiente para realizar la tarea.

La revolución de 1868 , como así la denomina también Parejo, es una verdadera revolución con marcada participación popular a través de las Juntas locales revolucionarias. Su finalidad es instaurar un régimen democrático (48). El nuevo Gobierno, integrado por progresistas y unionistas, se ocupa de inmediato de la cuestion local.

Los Decretos de 21 de octubre y 9 de noviembre de 1868 restablecen la Ley de 1856 y regulan la forma en que han de hacerse las elecciones de ayuntamientos, diputaciones provinciales y diputados a Cortes. Los nuevos textos ofrecen variaciones de alcance histórico en relación con la elección del alcalde.

Por primera vez en nuestra historia se institucionaliza la elección del alcalde por mayoría relativa de votos de los concejales elegidos por los electores. Hasta el momento presente, la máxima autoridad municipal había sido elegida por los vecinos o nombrada por la autoridad estatal de entre los concejales electos, salvo el supuesto de designación discrecional del alcalde-corregidor. La merma democrática que supone la elección indirecta asegura, sin embargo, una racionalidad funcional en cuanto que el alcalde electo dispone de la mayoría concejil para desempeñar su función. En este sentido, el legislador adapta la organización del ayuntamiento al sistema parlamentario en cuanto que el alcalde-presidente es elegido por los representantes y no por los electores. Sin embargo, esta fórmula no conseguirá en el futuro una consolidación definitiva, como se verá en las páginas siguientes.

La base electoral descansa ahora en el sufragio universal restringido, pues no sólo continúan votando los hombres, sino sólo los mayores de veinticinco años cabezas de familia. La legislación gaditana concedía el derecho de sufragio a los mayores de veintiún años y no les exigía esta útima condición.

Las leyes municipal y electoral de 20 de agosto de 1870 se elaboran todavia en el flujo revolucionario aunque tienen patente progresista. La corporación elige de nuevo, como en los textos de 1868, por mayoría absoluta del número total de concejales al alcalde. Los electores son los varones mayores de veinticinco años

(48) PAREJO. L.: La región y la legislación histórica del régimen local. Las autonomias regionales, Instituto Nacional de Prospectiva, Presidencia del Gobierno, Madrid, 1977, p. 83. 
y los elegibles, además, deben ser cabezas de familia y tener cuatro años ininterrumpidos de residencia en el pueblo, salvo los naturales que después de una ausencia prolongada hayan obtenido la declaración de vecindad (49).

Junto a la anterior limitación de sufragio, el pensamiento progresista censitario aflora de modo especial en la creación de la Junta Municipal. Esta tiene atribuidas funciones decisivas municipales, como la aprobación de los presupuestos de gastos e ingresos, el establecimiento y creación de arbitrios y la censura y revisión de las cuentas municipales. Y este nuevo órgano está integrado por los miembros del ayuntamiento y una asamblea de vocales asociados en número igual al triple del de concejales... designados de entre los contribuyentes del municipio por sorteo (50). Castelar no podía menos de ver en esta Junta un falseamiento del sufragio universal en razón de su carácter censitario y aleatorio (51).

El permisivo intervencionismo progresista de 1856 en la vida corporativa se mantiene también en el texto de 1870. La desobediencia grave al gobernador y ministro de la gobernación así como la «extralimitación grave con carácter político acompañada con publicidad del acto, excitación a otros ayuntamientos a cometerlo y/o producir alteración de orden público» acarrea la suspensión de los individuos del ayuntamiento y por consiguiente y sobre todo del alcalde. Esta se impone conjuntamente por el gobernador y la Comisión Provincial, y en supuesto discrepante se eleva al Gobierno. De proceder la destitución éste manda pasar los antecedentes a los tribunales, únicamente competentes para sentenciar tal medida extrema (52). Como era esperado los diputados federalistas rechazaron este intervencionismo gubernativo en el ayuntamiento, incluso para $\mathrm{Pi}$ y Margall por simple incoherencia con la autonomía municipal predicada por la ley y articuladamente incumplida (53).

La efímera existencia de la Primera República imposibilita la referencia legal propia. No obstante, la Ley de 24 de junio de 1873, de renovación total de los ayuntamientos, reconoce el derecho electoral a todos los españoles mayores de veintiún años. Las graves alteraciones públicas de este régimen democrático no excepcionan tampoco a las elecciones municipales. La Ley de 18 de

(49) Ley electoral, arts. 1 y 6 , y Ley municipal, art. 39

(50) Ley municipal, arts. 28-32 y 59-65. Véase MORELL OCAÑA, L., y LÓPEZ-FONT, J. F.: "Las Juntas municipales en el régimen local español del siglo XIX», en Revista de Administración Pública, núms. 100-102, vol. III. pp. 2203-2237

(51) Diario de Sesiones de las Cortes Constituyentes de 1869-1871, sesión de 11 de mayo de 1870 , p. 7882.

(52) Ley municipal de 20 de agosto de 1870, arts. 159-190. 8160 .

(53) Diario de Sesiones de las Cortes Constituyentes del 1869-1871, pp. 7888, 7918 y 
agosto de 1873, al suspender la toma de posesión de los concejales electos en las provincias que hubieran perturbado el orden público, está reconociendo la existencia de unos comicios celebrados bajo los signos de la improvisación y alteración pública. El dato siguiente es inequívocamente demostrativo: la elección se convoca por la mencionada Ley de 24 de junio, ésta se publica el dia 26 y los comicios deben celebrarse en los días $12,13,14$ y 15 de julio... como es obvio ni siquiera el nuevo censo electoral podía estar confeccionado.

\subsection{6-1923: Nombramiento gubernativo de los alcaldes de los ayuntamientos importantes entre los concejales moderados}

La restauración monárquica de 1875 restaura el pensamiento moderado de 1845. Las espadas en alto, la Ley de 1870 es progresista, la de 16 de diciembre de 1876 deroga su representatividad municipal y la de 2 de octubre de 1877 es ya definitivamente un texto moderado, obra de los antiguos unionistas y moderados que ahora se denominan liberales-conservadores. Resulta certera para nuestra materia de estudio la afirmación de Miguel Artola: «La Constitución de 1876, desarrollo formal de una pretendida Constitución interna, no es en realidad sino la vuelta a la fórmula moderada de 1845» (54).

Este largo período no es en absoluto pacífico, aun desde su dimensión legislativa de régimen local, pues si bien es cierto que el texto de 1877 está vigente hasta 1923 a); otras disposiciones legales lo modifican en determinados aspectos $b$ ), y sobre todo, un gran número de proyectos de ley de régimen local demuestran, de manera inequívoca, que la reforma era necesaria c).

a) La Constitución de 1876, artículo 83, repite el 73 de la de 1845: «Habrá en los pueblos alcaldes y ayuntamientos. Los ayuntamientos serán nombrados por los vecinos a quienes la ley confiera este derecho.» Se silencia de nuevo la representatividad del alcalde y se remite a la ley la regulación del sufragio activo y pasivo vecinal. El mantenimiento de la Junta Municipal, además, con un carácter censitario exclusivo confirma, como así lo han escrito S. Martín Retortillo y Argullol, la ecuación cuidadano igual a propietario (55).

La intervención gubernativa en el nombramiento de los alcaldes de 1877 se diversifica con un sentido altamente pragmático $\mathrm{V}$

(54) ARTOLA, M.: Ob. cit., p. 322

(55) MARTIN-RETORTILLO, S. (dirección): Descentralización administrativa y organización política, Alfaguara, Madrid, 1973, tomo I, p. 193 
despojado ya de razonamiento doctrinal: en Madrid, al alcalde lo nombra libremente el Rey e incluso a los tenientes, aunque en el nombramiento de estos últimos debe limitarse a los concejales del ayuntamiento. También en los ayuntamientos de las capitales de provincia, de los cabeza de partido judicial y de aquellos otros que perteneciendo al mismo partido tengan igual o mayor vecindario, siempre que no bajen de 6.000 habitantes. En los demás pueblos de España, los alcaldes serán elegidos por y de entre los mismos concejales.

El Gobierno asume directamente el nombramiento con un criterio político pragmático: la importancia política del municipio, ya sea esta social y demográfica -Madrid, capitales de provincia y de partido judicial- y demográfica -mayores de 6.000 habitantesaconsejan la dependencia gubernativa del alcalde. Incluso, esta Ley y sus autores, de mucha mayor altura política que los moderados de 1845, no preceptúan el nombramiento sino que astutamente lo facultan: "el Rey podrá nombrar...» ¡Para qué nombrar alcaldes cuando el ayuntamiento sea políticamente progubernamental! Resulta sorprendente el mantenimiento del sofisma moderado de la designación gubernativa del alcalde por el administrativista Fernando Mellado en 1899: «Entendemos como más perfecto, aunque no en absoluto, el nombramiento por el poder central de entre los concejales, porque debiendo representar el alcalde al pueblo y al Gobierno, la elección le da legítima representación del pueblo y el nombramiento del Gobierno la representación del poder central» (56). Este razonamiento doctrinario ya en 1845 partía de dos premisas equívocas como eran, primera, que el alcalde representaba al pueblo cuando el sufragio censitario sólo le permitía representar a los mayores propietarios del pueblo y, segunda, que se puede representar parcialmente al Gobierno de la nación sin ser nombrado necesariamente por él. En 1877, la propia ley quiebra absolutamente la argumentación referida: al alcalde de Madrid lo nombra exclusivamente el Gobierno y los de los municipios pequeños los concejales. Incluso, a los alcaldes de los demás ayuntamientos pueden elegirlos solamente los concejales si el Gobierno no hace uso de su facultad designativa.

El texto de 1877 posibilita la suspensión de los alcaldes por causa grave. No obstante, junto a la vaguedad de la causa suspensiva - icausa grave!- se exclusiviza la potestad en el gobernador civil y se prescinde de la Comisión provincial. Como en la

(56) MELLADO, F.: Tratado elemental de Derecho Administrativo, tercera edición, Madrid, 1899, p. 207. SANTAMARIA DE PAREDES relaciona igualmente la doble representación del alcalde y su forma de nombramiento, aunque no extrae conclusiones como lo hace MELLADO SANTAMARiA DE PAREDES V.: Curso de Derecho Administrativo, octava edición, Madrid, 1914. página 195 
legislación progresista anterior es el Gobierno quien resuelve finalmente y del mismo modo son los tribunales los únicos que puden fallar la destitución.

El criterio general para ser elector es el de contribuyente, mayor de veinticinco años y cabeza de familia. De igual modo se le reconoce el derecho de sufragio activo al empleado público y al titulado oficial. El sufragio pasivo se restringe a los mayores contribuyentes, en proporción directa al número de vecinos del respectivo municipio. El pensamiento conservador vuelve a definir su credo y razón de la vida pública: el interés. "Entre la fuerza numérica, pues, y los intereses, la comisión ha aceptado el criterio de dar representación a los intereses, porque los intereses, después de todo, son los únicos que pueden venir a disponer lo que constituye la vida, la esencia y el fundamento de las corporaciones locales... y el sufragio universal es una utopía, una ilusión...», incluso, Romero Robledo se atreve a afirmar que este derecho es "un instrumento de tiranía y enemigo de la libertad» (57).

Castelar se opone al texto y defiende mejor que ningún otro diputado de la oposición el sufragio universal. Advierte del peligro que corre una sociedad que tiene un gran número de individuos fuera del derecho. Descalifica el principio del censo y lo considera como el principio de alcance más terrible y de más terribles consecuencias en cuanto cimenta el derecho exclusivamente en el dinero y... unuestro pueblo puede ser un pueblo perturbado, pero no es un pueblo corrompido, ni mucho menos un pueblo degradado» (58).

b) Durante este largo período histórico de vigencia de la Ley de 1877, otros textos legales modifican, de manera directa o indirecta, la elección del alcalde. Los tres de mayor alcance derogatorios son los siguientes.

La Ley electoral de 26 de junio de 1890 aplica el sufragio universal para las elecciones de diputados a Cortes, en virtud del artículo adicional primero, a las de concejales y diputados provinciales. El Real Decreto de 5 de noviembre de 1890 adapta el texto a los comicios locales. Son electores todos los españoles varones, mayores de veinticinco años, que se hallen en el pleno goce de sus derechos civiles y sean vecinos del municipio con dos años al menos de residencia. Esta reforma es obra del partido liberal. La Ley de 9 de julio de 1898 aplica al municipio de Barcelona el régimen excepcional establecido para Madrid de nombramiento real del alcalde y tenientes. La Ley electoral de 8 de agosto de 1907,

(57) Diario de Sesiones del Congreso, legislatura de 1876 a 1877, sesión de 26 de junio de 1876, pp. 2393, 2394 y 2414

(58) Ibidem, sesión de 17 de noviembre de 1876, pp. 3509-3510 
consciente del desprestigio y corrupción electoral general, se propone «sanear» y librar las impurezas de la función electoral. En este sentido $y$ en cuanto al tema que nos ocupa, establece la obligatoriedad del voto y el sufragio universal en los términos generales del texto de 1890 para los elegibles.

c) Los Proyectos de Ley Municipal presentados a las Cortes, ya al Congreso ya al Senado, son aproximadamente veinte (59). Textos conservadores son los de Romero Robledo en 1884, de Silvela-Sánchez de Toca en 1891, de López Puigcerver en 1884, de Dato en 1899, de Silvela en 1899, de Maura en 1903, de González Besada en 1905 referido a la hacienda municipal, de Maura-La Cierva en 1907. Los liberales son de Venancio González en 1882, 1886, 1887, 1888 y 1889, de Alfonso González 1901, de Moret en 1884 y 1902, de Romanones en 1906 y de Canalejas en 1912 (60). El texto de algunos proyectos suele ser el mismo con ligeras modificaciones. El más importante de los conservadores es desproporcionadamente el de Maura de 1907, mientras que el de Venancio González de 1889 y el de Canalejas de 1912 representan el pensamiento liberal.

El Proyecto de Antonio Maura de 1907, en la cuestión que nos ocupa, mantiene la vieja concepción moderada intervencionista en el nombramiento de la máxima autoridad municipal. La desconfianza a la voluntad popular en la elcción del alcalde se mantiene incólume: en los municipios de más de 20.000 habitantes, el Goierno podrá hacer o revocar el nombramiento del alcalde entre los concejales y en Madrid y Barcelona podrá hacerlo incluso en un vecino que no forme parte del ayuntamiento. Junto al alcalde por Real Orden se restaura el alcalde-corregidor: el gobernador civil puede nombrar en cualquier municipio un alcalde corregidor en sustitución del alcalde elegido para realizar las funciones delegadas del Gobierno en el pueblo. En este supuesto,el pueblo mantiene al alcalde elegido junto al alcalde corregidor nombrado que preside los actos públicos en primea posición y que representa al Gobierno de la nación. Los conservadores son los únicos defensores del Proyecto y los demás partidos parlamentarios se oponen a él.

El Proyecto de Ley de Bases sobre Régimen Local de 15 de octubre de 1912, presentado al Congreso por el ministro de la gobernación Antonio Barroso, refleja el pensamiento del presidente Canalejas en este momento histórico en que los liberales y los

(59) JORDANA DE POZAS, como contabilizara anteriormente CALVO SOTELO, fija el número de veintidós Proyectos de Ley presentados desde 1877 a 1923. JORDANA DE POZAS L.: Cincuentenario del estatuto municipal, Instituto de Administración Local, Madrid, 1975, p. 18.

(60) Los textos de los proyectos, así como los discursos parlamentarios más destacados del de 1907 se encuentran en COSCULLUELA. L., y ORDUÑA, E. I.: Legislación sobre Administración local, 1900-1975, tomo I, Instituto de Estudios de Administración Local, Madrid, 1981 
conservadores deben mantener el equilibrio del sistema frente a los republicanos, socialistas, regionalistas, carlistas y alguna otra minoría. El texto se presenta conciliador con los postulados conservadores. Incorpora la representación concejil corporativa. EI alcalde es elegido sólo por los concejales populares y no por los corporativos de entre los mismos ediles o de entre los vecinos del pueblo, aunque en este supuesto es necesaria una mayoría de dos tercios de los votos concejiles; sin embargo, y esta es otra clara dejación liberal, en los municipios de más de 150.000 habitantes el Gobierno puede nombrar el alcalde. Canalejas es asesinado el 12 de noviembre de 1912 y el Proyecto muere también con él.

\subsection{3-1930: La demagogia formal de la electividad democrática del alcalde}

La ausencia de respuesta legislativa del Parlamento español durante la restauración al problema local y de manera concreta a la representatividad viene a darla la dictadura del general Primo de Rivera. ¿Cómo resuelve el problema caciquil y regenera la vida municipal, después del golpe de Estado de 13 de septiembre de 1923, el nuevo Gobierno militar? Con dos textos legislativos principalmente: el Real Decreto de 30 de septiembre de 1923 a) y el Real Decreto-ley de 8 de marzo de 1924 b). Por el primero se positiviza la representatividad municipal menos democrática de la historia analizada de España y por el segundo una de las más democráticas de este mismo período. La aparente contradicción se encuentra contemplada y resuelta en la disposición final del segundo, por el estatuto «entrará en vigor el día primero de abril próximo, salvo aquellos de sus preceptos que se refieren a la celebración de elecciones y constitución de corporaciones municipales... Igualmente quedarán en suspenso todas las disposiciones de esta ley, cuya aplicación exija la intervención del cuerpo electoral hasta que se apruebe el nuevo censo». Jamás se celebraron elecciones y constituyeron ayuntamientos de conformidad con el Estatuto municipal.

a) El Real Decreto de 30 de septiembre de 1923 dispone el cese de todos los concejales y por consiguiente también de los alcaldes constitucionales de los ayuntamientos. Estos se forman con los vocales asociados de las Juntas Municipales. El alcalde es elegido por los nuevos concejales-vocales asociados de entre sí y las condiciones no son otras que la de ostentar título profesional o ejercer industria técnica o privilegiada $y$, en su defecto, ser mayor contribuyente. El mencionado Real Decreto posibilita el nombramiento gubernativo de las máximas autoridades municipales en las 
poblaciones de más de cien mil habitantes. Debe mencionarse, además, que los actos «electivos» están presididos e intervenidos por la autoridad militar.

Dos nuevos textos jurídicos precisan y configuran la representatividad municipal de la dictadura primorriverista: el Real Decreto de 20 de octubre de 1923 y la Real Orden de 4 de febrero de 1927. El primero de estos crea los delegados especiales de los gobernadores civiles -más bien militares en esta época- en las cabezas de los partidos judiciales. Son nombrados con toda libertad y de manera conjunta por los ministerios de la gobernación y de la guerra entre los jefes o capitanes del ejército por un año y para que intervengan en el funcionamiento de los ayuntamientos, ayudándoles y orientándoles a desenvolver su vida. Por la Real Orden citada se atribuye al gobernador la libre designación de los concejales dimitidos entre los suplentes.

La propia literalidad de los textos referidos fundamenta suficientemente la afirmación inicial de que la representatividad primorriverista es la más antidemocrática de nuestra historia estudiada: los ayuntamientos y las Juntas Municipales están integradas de modo exclusivo por contribuyentes. El sorteo sustituye a la elección concejil. La autoridad militar preside e interviene la constitución de las nuevas corporaciones. Los delegados gubernativos, militares, intervienen la vida municipal. Finalmente, los gobernadores nombran sustitutos a los concejales dimitidos. La primera dictadura de nuestro siglo $\mathrm{XX}$ quiebra todo pensamiento conservador como liberal sobre esta materia y manifiesta inequívocamente su naturaleza militar y burguesa.

b) La representatividad del Estatuto, denominación ecléctica como asi lo pone de manifiesto el mismo Calvo Sotelo, «que no declaraba el origen del cuerpo legal y lo vistió con ropaje de eficiencia suprema" (61) es formal y contrariamente una de las regulaciones legales más democráticas de la historia de España hasta este momento.

El alcalde es elegido por los respectivos ayuntamientos entre los concejales o los electores con capacidad para ser concejales. En el primer caso basta la mayoría absoluta de votos de la corporación y en el segundo son precisas dos terceras partes. La primera reelección exige el acuerdo de las dos terceras partes de los concejales y las siguientes preceptúan el referéndum. Tanto las dos terceras partes de los concejales como el electorado a través del referéndum pueden destituir al alcalde.

(61) Calvo Sotelo, J.: Mis servicios al Estado. Seis años de gestión. Apuntes para la historia, Madrid, 1931, p. 30. 
Calvo Sotelo manifiesta en la exposición de motivos del Estatuto que «las supresiones y destituciones gubernativas quedan suprimidas en absoluto. En lo sucesivo no habrá tampoco concejales gubernativos, por eso cada titular tendrá un suplente, hijo como él de la elección. Los miembros del ayuntamiento sólo pueden ser suspendidos y destituidos por auto de la Audiencia Provincial. La garantía no puede ser más eficaz y firme». No obstante, en las funciones estatales realizadas por el alcalde, el Gobierno podrá retirarle esta delegación en favor de un concejal, pero sin afectar el status jurídico de la máxima autoridad municipal.

La concepción democrática del Estatuto se evidencia además en el reconocimiento del derecho de sufragio, tanto activo como pasivo, a los varones mayores de veintitrés y veinticinco años; respectivamente, $y$ a las mujeres de la misma edad, siempre que sean cabeza de familia. La incorporación de la representatividad corporativa concejil recoge el pensamiento conservador y liberal de los proyectos mencionados, aunque disminuye su importancia comparativa en relación a éstos.

El alcalde de la dictadura primorriverista es el primero de los mencionados, pues el del Estatuto debe ser considerado como una ficción y un canto demagógico a la democracia municipal.

\subsection{0-1936: La fórmula democrática alternativa de la elección concejil o popular del alcalde}

La caída de la dictadura con la dimisión de Primo de Rivera se produce el 29 de enero de 1930. Al día siguiente se forma nuevo Gobierno, presidido por el general Berenguer, y quince días más tarde, por Real Decreto de 15 de febrero, se cesa a todos los miembros de los ayuntamientos. La nueva representatividad municipal transitoria asocia a los mayores contribuyentes del municipio y a los concejales que en el momento anterior a 1923 hubieran desempeñado el cargo en virtud del sufragio popular. Los ayuntamientos así constituidos rigen y administran los intereses del municipio con arreglo al Estatuto municipal, cuya vigencia subsiste en todo lo no incompatible con el Decreto citado. Finalmente, las reclamaciones las resuelve el Gobierno civil. El nuevo régimen no supone un cambio significativo con la representatividad municipal primorriverista.

La dictadura y la situación provisional que viven los ayuntamientos -y también el Gobierno de la nación- determina que, como ha señalado Miguel Artola, la cuestión electoral constituya el objeto prioritario de los Gobiernos que siguen a la dictadura, por cuanto sólo unas elecciones suficientemente libres podian reconstruir el 
consensus nacional en torno al régimen (62). La Monarquía pues, necesitando volver a los fundamentos de su constitucionalidad, convoca elecciones municipales para posteriormente realizar las generales.

El Real Decreto de 13 de marzo de 1931 convoca elecciones municipales para el 12 de abril. La representatividad es la anterior a la dictadura, la de la Ley de 1877 y la de la Ley Electoral de 1907: el sufragio universal masculino activo y pasivo de los mayores de veinticinco años. La trascendencia de estos comicios en la historia de España es decisiva, pues, aunque jurídicamente resulta esperpéntico, hay una conciencia generalizada de que lo que se juega realmente no es la elección de los concejales, sino la forma de Estado monárquica o republicana. Esta conciencia del envite y los resultados electorales, donde los republicanos obtienen una gran mayoría en las capitales de provincia, determinan proclamaciones espontáneas de la Segunda República y la salida de Alfonso XIII al exilio (63).

Sin nuevas elecciones municipales durante todo este período, salvo los comicios parciales de 23 de abril de 1933 para los municipios administrados por comisiones gestoras, la segunda República carece de una ley municipal propia y vive su anómala existencia en esta materia con los textos de Cánovas, Maura y Calvo Sotelo. Sólo, al final, se publica la Ley Municipal del 31 de octubre de 1935, que carece de práctica electoral alguna.

Como anteriormente lo hiciera el Estatuto Municipal, la Ley republicana, artículo 73 , dispone que los alcaldes eran siempre designados por elección directa del pueblo o por el ayuntamiento. La reelección de este último sólo se posibilita una vez, mientras que la del primero indefinidamente.

La alternativa legal de un alcalde de elección popular ofrece un peculiar procedimiento electivo. Se necesita un número determinado de firmas de electores para presentar la candidatura, una antevotación para la proclamación de todos los candidatos que obtengan un número de votos igual a la décima parte de los electores y la exigencia para poder ser proclamado alcalde, además de ser candidato más votado, de obtener como mínimo la tercera parte del censo electoral. Las exigencias legales establecidas no tienden a favorecer la figura del alcalde popular, y la ausencia de práctica imposibilita valoración real alguna.

Como lo hiciera el Estatuto Municipal, la Ley republicana regula la destitución del alcalde: Si la elección ha sido corporativa se exige

(62) ARTOLA M.: Ob. cit., p. 593

(63) Sobre los resultados electorales de 12 de abril, véase ARTOLA, M.: Ob. cit., pp. 593-598. MARTínez CUADRADO, M.: Elecciones y partidos políticos de España (1868-1931), Taurus, Madrid, 1969, pp. 853-857. 
la mayoría absoluta de los concejales que integran el ayuntamiento o la mitad más uno del cuerpo electoral, mientras que si aquélla ha sido vecinal sólo podrá realizarse de este mismo modo (64).

La intervención gubernativa en la formación y constitución de los ayuntamientos es prohibida expresamente por el artículo 50 de la Ley; no obstante este principio general de autonomía se excepcionaliza en el supuesto de que la provincia a que pertenezca el término municipal se halle en alguno de los tres estados de prevención, alarma o guerra definidos por la Ley de Orden Público. En estos casos el Gobierno puede suspender al alcalde y nombrar como interino a un concejal. Aquél continúa desempeñando su cargo concejil y recupera la alcaldía automáticamente tan pronto como se restablezca la normalidad constitucional o lo dispusiere el Gobierno (65).

El principio de autonomía municipal constitucionalizado fundamenta las enmiendas que la oposición formula a esta injerencia gubernativa en el ayuntamiento. Calvo Sotelo recuerda que el Estatuto sólo posibilitaba al Gobierno suspender al alcalde de sus funciones como delegado suyo, pero jamás en el cargo de alcalde, $y$, del mismo modo, el diputado vasco Irujo se oponía a este quebranto constitucional del artículo 9. ${ }^{\circ}(66)$. La situación de anormalidad continuada de la vida española explica esta tutela suspensiva y sustitutiva sobre el alcalde, aunque no la justifica necesariamente.

La legislación republicana municipal positiviza, de modo general y por primera vez, el sufragio universal en nuestra historia: Todos los vecinos, hombres y mujeres, mayores de veintitrés años, eligen y pueden ser elegidos -sabiendo leer y escribir- concejales $y$, en su caso, alcalde del municipio. Desgraciadamente, la elección democrática no se realiza. El Decreto de 17 de marzo de 1936 convoca elecciones municipales para la renovación total de todos los ayuntamientos, de conformidad con la Ley Municipal de 1935 , pero el Decreto de 3 de abril suspende estos comicios que debían celebrarse el 12 de abril de 1936. Las urnas electorales serán sustituidas por las armas como legitimación del poder.

(64) Ley municipal de 31 de octubre de 1935, arts. 75 y ss

(65) Ibidem, art. 80

(66) Diario de Sesiones de las Cortes, sesión de 13 de febrero de 1935, p. 6284, y sesión de 27 del mismo mes, p. 6782. 


\section{PERIODO DE 1936 A 1978}

\subsection{El periodo bélico. Una larga década de Comisiones Gestoras}

El régimen municipal de la Dictadura franquista legaliza su existencia durante la guerra civil. Ante esta situación anormal se recurre institucionalmente a un órgano de excepción, como es la Comisión Gestora. El Decreto de 30 de septiembre de 1936 sustituye el ayuntamiento por ésta en todos los municipios ex republicanos del territorio nacional.

La designación total de los miembros de los nuevos órganos municipales es libre para la autoridad gubernativa, aunque se dispone que éstos deberán integrarse por los mayores contribuyentes por rústica, industria, pecuaria y utlidades, siempre que reúnan las características del apoliticismo y de la eficiencia. No obstante, también pueden ser llamados a formar parte de estas gestoras cualesquiera otras personas que, en razón de sus actividades o por su significación personal, puedan estimarse como de leal e imprescindible cooperación, así como las representaciones de agrupaciones obreras que, por su ideología, puedan ser consideradas como afectas al Movimiento salvador de España.

Estos textos evidencian la política ambiguamente abierta exigida en los comienzos de la guerra para la adhesión del mayor número de personas a la causa del Movimiento, y de ahí la invocación del apoliticismo y eficiencia como determinantes del nombramiento. Sin embargo, la designación gubernativa de los representantes municipales según criterios preferenciales de riqueza -mayores contribuyentes- e ideología -leal e imprescindible cooperación (afección al Movimiento) - ya caracterizan y cimentan legal y/o realmente la representatividad municipal franquista hasta el final de su vigencia.

La Orden de 30 de octubre de 1937 significa ya un paso decisivo tanto en la pretensión definidora del nuevo Estado como en los criterios sustentadores del régimen municipal. El «control exacto» que sobre la Administración local española debe tener el nuevo Estado totalitario exige que los ayuntamientos se regenten «por personas no sólo afectas al Movimiento Nacional, sino que sintiéndole hondamente aporten al mismo en todos sus aspectos e intensidad lo que él requiere, y de ahí que tanto la provisión de vacantes como las sustituciones se realicen sólo por personas que reúnan estas garantías; bien entendido, positiviza el texto, que las propuestas nunca podrán recaer sobre personas que hayan pertenecido a organizaciones integradas en el frente popular». 
La centralización designativa es absoluta, pues el Gobierno es quien nombra y cesa a todos los miembros de las Comisiones Gestoras; no obstante la propuesta la realiza para la respectiva provincia el gobernador civil, quien, por exigencia de la primera instrucción, debe acompañar aquélla de su juicio personal, tras el asesoramiento de.los jefes de puesto de la Guardia Civil, jefe local de la FET y de las JONS del pueblo a que afecte el cargo a cubrir y el respectivo provincial, así como el de otras personas que por su independencia puedan ofrecer garantía en el asesoramiento (67).

Los municipios «liberados» con posterioridad al 1 de febrero de 1938 son objeto de un régimen transitorio que, en la materia que nos ocupa, dispone que el nombramiento de los miembros de las Comisiones Gestoras sea realizado por el gobernador civil, siempre que no lo hubieran sido ya por la autoridad militar, e incluso faculta a éste para nombrar al alcalde con todas las atribuciones de la Comisión Gestora (68).

La excepción señalada al ejercicio de la libre y total designación ministerial de los alcaldes y miembros de las Comisiones Gestoras de toda España desaparece tres años después. La Orden de 11 de julio de 1942 restituye al Ministerio la facultad delegada a los gobernadores civiles, y consiguientemente la Orden de 30 de octubre de 1937 es quien regulará la representatividad hasta las primeras elecciones municipales de la Dictadura en 1948. Ayudado de la propuesta de los gobernadores civiles el Gobierno nombra y cesa a todos los miembros de las Comisiones Gestoras de todos los municipios de España.

\subsection{El nombramiento y cese del alcalde franquista}

La legislación ordinaria de régimen legal dispone que «en todos los municipios, con exclusión de los que tradicionalmente vienen funcionando en régimen de concejo abierto, habrá un ayuntamiento, designado en la forma que esta ley determina» (69). Este está compuesto por el alcalde, que lo preside, y por un número de concejales proporcionado a la población residente del término, y su número oscila entre 3 y 24, salvo los de Madrid y Barcelona, que cuentan con 36 .

\subsubsection{NOMBRAMIENTO}

Los alcaldes de los municipios con población de derecho superior a 10.000 habitantes son nombrados por el ministro de la

(67) Ley de 1 de octubre de 1936 y Decreto de 6 de octubre del mismo año.

(68) Decreto de 23 de junio de 1938, arts. 1 y 3

(69) Texto articulado y refundido de las leyes de bases de régimen local de 17 de julio de 1945 y de 3 de diciembre de 1953, aprobado por Decreto de 24 de junio de 1955, art. 72.

REVISTA DE ESTUDIOS.-5 
Gobernación, y los restantes lo son por el gobernador civil de la provincia, dando cuenta previamente a dicho ministro. La autoridad político-administrativa sólo se encuentra legalmente condicionada en el nombramiento a personas mayores de veinticinco años, pues las condiciones legales exigidas de «idoneidad, competencia y arraigo» en la localidad, al ser tan genéricas como indeterminadas, no pueden ser consideradas como limitaciones a la discrecionalidad nominativa (70).

El sistema franquista institucionaliza un procedimiento de nombramiento coherente con su propia racionalidad dictatorial. Otras fórmulas designativas también tenían asiento y fundamento legal dentro de los principios y leyes fundamentales del régimen, sobre todo después de la publicación de la Ley Orgánica del Estado, en enero de 1967, con su positivizada exigencia de que las Corporaciones Municipales fuesen elegidas por sufragio: Carro Martínez, en 1962, propone la elección del alcalde en los pequeños municipios -aunque admitiendo la posibilidad de limitarla a los concejales elegidos- y mantiene la designación en los grandes (71). Este mismo autor propone en 1967 tres procedimientos posibles para la elección-designación de todos los alcaldes mediante la propuesta de los concejales y el nombramiento de entre éstos por el gobernador civil o el ministro de la Gobernación, según el municipio tuviera una población inferior o superior a los 10.000 habitantes (72). Cruz Hernández puntualiza, como conclusión de un seminario sobre representatividad municipal, «que el principio de elección del alcalde por la Corporación Municipal de entre la terna presentada por el gobernador civil, debe extenderse a los municipios de hasta 20.000 habitantes» (73). Fernández Júlbez y Martín Mateo, en 1968, y entre las conclusiones de un seminario sobre bases de reforma de la Ley de Régimen Local, apuntan para la designación de alcalde la propuesta por los concejales electos de una lista igual de candidatos al número de la Corporación respectiva al gobernador civil, quien a su vez remitiría a ésta un número proporcional de candidatos, seleccionados de dicha lista y de los propios concejales, que no sería superior a la cuarta parte ni inferior a tres. Los concejales eligirían alcalde de entre los propuestos por la autoridad (74). Garrido Falla, en 1971, propone la elección del alcalde por los

(70) Ibidem, arts. 60 y 62

(71) CARRO A.: "La problemática local en España», en Problemas políticos de la vida local, 1962, pp. 328-329

(72) CARRO A.: «La representatividad en la vida local», en Problemas políticos de la vida local, 1967, pp. 144-145.

(73) CRUZ HERNÁNDEZ M.: «Revisión de la legislación electoral a efectos de la representación municipal, en Problemas políticos de la vida local, 1967, p. 383

(74) FeRnÁndez JúlBez G., y MARTín MATEO R.: "Bases para la reforma de la ley de Régimen Local», en Problemas políticos de la vida local, 1968, pp. 247-248. 
concejales familiares, sindicales y de entidades, bien entre ellos mismos o incluso entre extraños a la Corporación (75). Vasallo Rubio, en 1972, ofrece varios procedimientos alternativos de nombramiento, caracterizándose todos ellos por una conjunción de propuestas de la Corporación y de designación gubernativa o de propuesta gubernativa y elección corporativa (76). Morell Ocaña, en 1974, rechaza, por exigencia del artículo 46, II, de la Ley Orgánica del Ȩstado, la libre designación gubernativa; pero mantiene la designación gubernativa, aunque ésta debería limitarse necesariamente a un miembro electo, como se establecía en el Proyecto de Ley de 1840 (77).

Una opinión doctrinal excepcionalmente discrepante debe ser referida. Cirilo Martín-Retortillo, en 1958, escribe que "tanto la doctrina científica como el sentido popular propugnan porque sean las Corporaciones las que designen a sus presidentes... Hubiera sido más acertado que el alcalde fuese elegido por la Corporación, precisamente de entre los concejales que componen la misma; asi se lograría que en su gestión se acusara un verdadero sentido de responsabilidad y una mayor solidaridad con los concejales, cosa que no acontece cuando la designación se debe a la merced del gobernador $y$, por otra parte, la función tendría a una permanencia independiente de los cambios de dicha autoridad, que en muchos casos provoca una situación de interinidad para aquellos alcaldes designados por el gobernador que cesa» (78).

La libre designación jerárquica-piramidal se mantiene inalterada en los textos legales hasta la muerte oficial de Franco, el 20 de noviembre de 1975. las debidas condiciones personales de idoneidad, competencia y arraigo en la localidad son términos tan indeterminados y de tan subjetiva apreciación que no significaban para los sucesivos ministros y gobernadores civiles del régimen límite legal ni reglamentario en el nombramiento. Incluso la idoneidad y competencia sólo pueden ser atribuidas realmente a una persona en el ejercicio del cargo. Marqués Carbó así lo interpretaba, y en la coherencia del régimen valoraba esta fórmula, pues «no eligiéndose los alcaldes por el pueblo, es mejor no precisar y dejar que la superior autoridad, que nombra, tenga libres las manos para

(75) GARRIDO FALLA, F.: «Límites constitucionales de la reforma de la Ley de Régimen Local en materia de elecciones municipales», en Revista de estudios de la vida local núm. 169. 1971, páginas 7-8.

(76) VASALLO RUBIO J. L.: "La representatividad en las Corporaciones locales», en Problemas políticos de la vida local, 1972. np. 94-95.

(77) MORELL OCAÑA, L.: "La Administración local», en la obra dirigida por M. FraGA, J. VELARDE y S.DEL CAMPO: La España de los setenta, vol. III, tomo II, Moneda y Crédito, Madrid, 1972. pp. 140-141

(78) MARtin-Retortillo, C.: Ley de Régimen Local (Texto refundido de 1955), Aguilar. Madrid, 1958, p. 38 
escoger la persona más adecuada» (79). Jordana de Pozas, refiriéndose al último de los tres términos, corrobora la interpretación dada, pues «la legislación, al exigir el arraigo en la localidad, para no definir en qué consiste, lo deja a la apreciación discrecional del que ha de nombrar al alcalde. Creemos -propone el citado profesor- que esta laguna debiera colmarse por vía reglamentaria» (80). En este sentido se manifiesta Cirilo Martín-Retortillo al escribir que «queda, según el texto de la Ley, a la discrecionalidad del ministro o del gobernador la apreciación de las mismas y, por ende, no vemos recurso alguno en el orden legal para impugnar estos nombramientos» (81).

La designación por vía jerárquica, «cuya verdadera razón por la que el Gobierno juzga convenientemente nombrar a los alcaldes es la de controlar el poder e influencia política que tienen», según Jordana de Pozas (82), remite a un sistema en el que toda autoridad se convierte en subordinada de la superior, de la cual depende por entero. $Y$ es necesario poner en evidencia que aunque la coherencia, simplista desde luego, pueda aparecer en el modelo jerárquico piramidal administrativo o weberiano, éste no puede ser equiparado al sistema de dictadura personal franquista. En el caso que nos ocupa, la jerarquía se impone a cualquier autoridad del país, prescindiendo de toda voluntad de cuerpo o comunidad social, de cualquier criterio de conocimiento profesional $y$, sobre todo, de marco institucional asentado en la responsabilidad objetiva. Pero aurı desde la lógica propia del modelo, y «dejando a salvo el recto proceder y buena fe de los gobernadores, no hay duda que ofrece serio peligro el que sean estas autoridades las que nombren los alcaldes en los municipios de menos de 10.000 habitantes,... ya que forzosamente, ante la imposibilidad de un conocimiento perfecto de las personas que hayan de proponer o elegir, no tendrán más remedio que utilizar las "informaciones" no siempre depuradas y exentas de pasión morbosa que le faciliten» (83). La obvia y grave objeción de Cirilo Martín-Retortillo nos remite a un otro "sistema» paralelo de poder e influencia política en el que de miles de decisiones políticas no sabremos nunca quiénes fueron sus autores materiales.

(79) MAROUÉS CARBÓ. L.: «El Derecho local español», Información municipal, Barcelona, 1958, p. 281.

(80) JORDANA DE POZAS. L.: «El alcalde en el Derecho y en la realidad española», Problemas políticos de la vida local, 1967, p. 333

(81) MARTÍN RETORTILLO C.: Ley de..., ob. cit., p. 39

(82) JORDANA DE POZAS L.: "El alcalde...», ob. cit., p.334

(83) Martín-Retortillo C.: Ley de..., ob. cit., p. 38. 


\subsubsection{CESE}

«Cualquiera que sea su forma de nombramiento, el alcalde cesará en sus funciones cuando, por razones de interés público, lo disponga el ministro de la Gobernación» (84). La norma evidencia por sí sola la existencia de un sistema estatalizador caracterizado de una omnipotencia absoluta. Dada la exigencia previa del cese para que se produzca el nombramiento, legalmente es el ministro de la Gobernación quien determina todo cambio de alcalde en los miles de municipios españoles. La discrecionalidad ministerial se encuentra incondicionada.

\subsubsection{El alCalde de Los ayuntamientos de MAdRID y BaRCELONA}

Los regímenes especiales de Madrid y Barcelona (85) peculiarizan el nombramiento y cese de sus respectivos alcaldes en relación al régimen general: En los dos municipios mayores de España, aquéllos son nombrados por el Jefe del Estado, a propuesta del ministro de la Gobernación, entre las personas que reúnan las condiciones referidas de mayoria de veinticinco años, idoneidad, competencia y arraigo en la localidad. Frente al carácter de duración indefinida del régimen general, en estos supuestos se fija la duración del mandato, pero dado que el Jefe del Estado puede cesarle en cualquier momento, en la práctica no existe diferencia sustantiva alguna.

\subsection{Los intentos acomodaticios del régimen franquista a una sociedad de exigencias democráticas municipales}

a) El Proyecto de Ley de Bases de Régimen Local de 13 de enero de 1972. El preámbulo explica los motivos de reformar la legislación local. En relación con la representatividad municipal se menciona el artículo 46.II de la Ley Orgánica del Estado como el fragmento que umarca la nueva pauta a seguir cuando dispone que: "Las Corporaciones municipales y provinciales... serán elegidas por sufragio, articulado a través de los cauces representativos que señala el artículo 10 del Fuero de los Españoles." Y es, precisamente, a este precepto al que se ha de adecuar ahora la composición de los órganos de gobierno de nuestros municipios y provincias».

El alcalde continúa siendo designado por el ministro de la Gobernación para los municipios de más de 10.000 habitantes y

(84) Ley de Régimen Local, texto articulado y refundido de 1955, art. 62.3.

(85) Las leyes de los municipios de Barcelona y Madrid son, respectivamente, de 23 de mayo de 1960 y de 11 de julio de 1963. 
por el gobernador civil en los restantes. Sin embargo, y aquí radica la reforma, aquél debe limitarse en la designación a los miembros de la Corporación o a cualquiera de la terna propuesta por esta misma, mientras que al segundo se le limita sólo a cualquier concejal. Consiguientemente, se reduce el ámbito personal de la designación; pero se mantiene el dedo gubernativo. La duración indefinida del mandato del alcalde se limita al período de seis años (86).

El Proyecto de enero de 1972 es retirado de las Cortes por el Gobierno el 12 de febrero de 1974. Una razón de capital importancia legislativa influye la decisión gubernamental: el elevado número de enmiendas que los procuradores presentan al Proyecto. Cuadernos para el Diálogo da la cifra de 5.000 enmiendas, algunas de éstas proponiendo la retirada del texto gubernamental (87). El tema especialmente controvertido es el de la representatividad, y dentro de éste, el de la elección del alcalde. El 12 de febrero de 1974, Carlos Arias, presidente del Gobierno, anuncia «la retirada del proyecto de Ley de Bases de Régimen Local y la remisión de un nuevo texto que tendrá entrada en estas Cortes antes del próximo 31 de mayo. Estimamos que la peripecia sufrida por el Proyecto actual abona suficientemente la oportunidad de la decisión. EI nuevo Proyecto, que atribuirá a los alcaldes y presidentes de Diputación carácter electivo...» (88).

b) La Ley de Bases del Estatuto de Régimen Local de 19 de noviembre de 1975 .

El Gobierno envía un Proyecto de Ley de Bases del Estatuto de Régimen Local a las Cortes dentro del plazo prometido. El texto es aprobado el 19 de noviembre de 1975 y publicado en el Boletín Oficial del Estado dos días después. El alcalde es elegido mediante elección secreta por los concejales del ayuntamiento. En la primera votación es necesario el voto favorable de las dos partes del número legal de concejales, y en la segunda, realizada entre los dos candidatos que hubieran obtenido mayor número de votos, basta la mayoría simple.

Cualquier vecino de la municipalidad, sea concejal o no, puede ser proclamado candidato, siempre que lo solicite de la Junta Municipal del Censo y reúna algunas de las condiciones estableci-

(86) Proyecto de Ley de Bases de Régimen Local, Boletin Oficial de las Cortes de $19 \mathrm{dt}$ enero de 1972, núm. 1178, base 7

(87) Cuadernos para el Diálogo, diciembre de 1973, p. 32

(88) Los diarios españoles publican al dia siguiente el discurso del Presidente del Gobierno, diario La Verdad, de 13 de febrero de 1974, p. 11 
das por la ley. De nuevo se dispone la duración del mandato en seis años y se posibilita el carácter retributivo del cargo (89).

La innovación electiva del alcalde en el régimen franquista difícilmente puede ser comprendida si, junto a la exigencia del artículo 46.ll de la Ley Orgánica del Estado, no se olvida la coetaneidad del fallecimiento oficial del Jefe del Estado, 20 de noviembre de 1975, con la aprobación y publicación de la Ley de Bases del Estatuto de Régimen Local de 19 y 21 del mismo mes y año. La nueva representatividad se sitúa en la posición intermedia de mantenimiento del régimen y la creciente exigencia social de la representatividad municipal electiva. Las condiciones establecidas para ser proclamado candidato a los cargos de alcalde y concejal evidencian el continuismo del régimen local franquista. La Ley mantiene la trilogía de cauces, y ello, como Morell Ocaña expresamente manifiesta, «pese a la fuerte artificiosidad del último tercio, imposible de justificar tanto en el plano de los principios como en el de la realidad práctica» (90). Sin embargo, esta mezcla ilógica de dos sistemas antagónicos, además de resultar textualmente vaga e incoherente $y$ procedimentalmente remitida al futuro -procedimiento electoral que, como señala Roca, desbordaría quizá el contenido del futuro texto articulado para adquirir rango de Ley independiente (91)-, no será articulada jamás.

c) Las elecciones municipales de 25 de enero y 21 de marzo de 1976.

El Decreto de 5 de diciembre de 1975, de conformidad con lo establecído en la Disposición transitoria primera de la Ley de Bases del Estatuto de Régimen Local de 1975, convoca elecciones para la totalidad de los alcaldes de capitales de provincia y de ciudades de más de 100.000 habitantes, exceptuándose Madrid y Barcelona por su régimen especial, y también para la mitad de los alcaldes de los restantes municipios no capitales, determinada por provincias y según la mayor antigüedad en el cargo. El Decreto de 26 de diciembre, retrasando una semana la fecha señalada por el anterior texto, fija el 25 de enero como día de la elección. Una última norma de igual rango, de 20 de febrero de 1976, señala el 21 de marzo del mismo año para la celebración de las elecciones de las alcaldías vacantes.

(89) Ley de Bases del Estatuto de Régimen Local de 19 de noviembre de 1975, base quinta.

(90) MORELL OCAÑA. L. "La nueva Ley de Régimen Local: I. El municipio», Revista Española de Derecho Administratico, núm. 8, 1976, p. 34.

(91) ROCA ROCA. E.: «La electividad municipal del Estatuto municipal al proyeco de Ley de Bases del Estatuto del Régimen Local», en el libro colectivo Cincuentenario del Estatuto municipal, Instituto de Estudios de Administración Local, Madrid, 1975, p. 279. 
La gran novedad de estas convocatorias radica en que la elección se limita exclusivamente a los alcaldes y, en consecuencia, son los concejales del régimen local de 1955 quienes los eligen. Los vecinos no intervienen en estos comicios.

Las cuestiones electorales de inserción en la prensa de propaganda relativa a candidatos a presidentes de las Corporaciones locales, la presencia en los medios de comunicación social del Estado y del Movimiento, de las asociaciones políticas y la utilización de emisoras de radiodifusión en campañas de propaganda de candidatos a la presidencia de las Corporaciones locales se regulan por decretos gubernamentles y no por una ley electoral (92). Consecuentemente, estas disposiciones reglamentarias evidencian una disposición gubernamental de "teledirigir» las elecciones de los máximos dirigentes locales a fin de mantener en estos puestos a personas adeptas al régimen franquista. Incluso, aún dentro de este régimen jurídico, los decretos de convocatoria están viciados de ilegalidad, como denuncia Boquera Oliver, por no haber sido informados previamente por el Consejo de Estado. No extraña que a este profesor no le parezca acertada la manera de regular la elección del alcalde y que desee que los próximos desarrollos de la Ley de Bases del Estatuto de Régimen Local sean mejores (93).

\subsection{Una interpretación del nombramiento y cese gubernativo del alcalde en el régimen franquista}

El nombramiento y cese de todos los miembros de las Comisiones Gestoras lo realiza el ministro de la Gobernación hasta 1948. El nombramiento de los alcaldes de los municipios mayores de 10.000 habitantes continúa dependiendo del mismo ministro, y el de los restantes, del gobernador civil de la respectiva provincia, aunque cesados todos por aquél, hasta 1976, de modo formal, y 1979 de manera definitiva. Jamás en la historia de España se ha desconsiderado hasta tal extremo la voluntad vecinal.

La guerra civil posibilita el triunfo de una dictadura antidemocrática y el abatimiento del sistema democrático de la segunda República. El nuevo régimen de 1939, como así lo ha recordado Nieto, tiene una visión totalitaria del Estado que había de reflejarse, como no podía ser menos, en el régimen local (94). El nuevo modelo estatal se reafirma de modo progresivo, aunque veloz, en

(92) Decreto y Ordenes de 9 de enero de 1976

(93) BOQUERA OLIVER, J. M.: "La elección del alcalde», Revista de Derecho Público, número 64, 1975 , pp. 223 y 228

(94) NIETO A.: "La organización local vigente: uniformismo y variedadi, en la obra dirigida por S. MARTIN-RETORTILlo: Descentralización administrativa..., ob. cit., t. II, p. 44. 
una dictadura personal de inspiración totalitaria de derechas. El centralismo es absorbente y asfixiante, y de ahi que la subordinación jerárquica es un puro trasplante del esquema militar. La obediencia en un sistema centralista se consigue en mayor grado si los órganos jerarquizados son unipersonales en vez de colegiados, pues el mandato tiene mayores garantías de aceptación, disciplina y ejecución en cuanto la sumisión e identificación de una sola voluntad a la del superior que es más fácil lograr que si fueran varias. La racionalidad del régimen franquista exigía tanto la subordinación de la Corporación Municipal a la Jefatura del Estado como la institucionalización del alcalde, órgano individual, como un caudillo de su respectiva Corporación, como así le califica García Oviedo (95).

Dada la muerte de demócratas durante la guerra civil, exilio y persecución posterior, y la sacralización del Jefe del Estado con su régimen, el alcalde se convierte en un eslabón -el último- de la cadena de mando estatal. A pesar de la victoria aliada en la segunda guerra mundial, del paso de los años, de las voces evolucionistas del propio régimen..., el texto legal continuó imperturbable porque, como fruto de las armas, su evolución hubiera sido una claudicación de los vencedores.

\section{LA ELECCION Y CESE DEL ALCALDE EN EL SISTEMA VIGENTE}

\subsection{Elección}

Antes de la Constitución de 27 de diciembre de 1978, y desde luego de la Ley reguladora de las Bases de Régimen Local de 2 de abril de 1985, se aprueba la Ley de Elecciones Locales de 17 de julio de 1978.

Las dos grandes tareas de las primeras Cortes constituyentes no son otras que la de elaborar una Constitución y las normas de las elecciones locales. Este último texto es, como así se ha señalado, anterior al primero. De nuevo, la importancia del poder municipal se evidencia en nuestra historia. $Y$ continuando nuestra tradición secular, la cuestión del alcalde se destaca de las demás en el debate parlamentario.

Excluido el nombamiento gubernativo de los alcaldes por exigencia democrática, la historia española ofrecía dos fórmulas electivas de la máxima autoridad municipal: La directa del electo-

(95) GaRcia OVIEDO, C.: "La materia de competencias y servicios en la nueva Ley de Régimen Local», Revista de Estudios de la Vida Local, núm. 55, 1951, p. 30. 
rado popular y la indirecta concejil, que, incluso, en los textos de 1924 y 1935 coexistían. Los constituyentes, dado el sistema de candidatura de listas adoptado, optaron por una fórmula combinatoria de ambas.

El proyecto de Ley de Elecciones Locales, obra del Gobierno de Unión de Centro Democrático, dispone que el alcalde sea el candidato primero de la lista más votada por los electores del respectivo municipio. La fórmula electiva es directa en cuanto es el número de los votos vecinales quien decide la alcaldía. Manteniendo la seria objeción restrictiva de democraticidad de la candidatura de lista bloqueada, la fórmula gubernamental es de elección directa.

El texto gubernamental, en una sociedad pluripartidista como la española, beneficia a las organizaciones políticas mayoritarias, mientras que a las pequeñas se les imposibilita todo acceso a la alcaldía. En la sesión del Pleno del Congreso de los Diputados de 9 y 10 de marzo de 1978 se acaba aceptando la enmienda del Partido Comunista: Será alcalde el candidato cabeza de lista que obtenga la mayoría de los votos de los concejales. La razón objetiva que fundamenta esta fórmula frente a la gubernamental es de carácter funcional. Con este texto se posibilita que alcaldes mayoritarios en votos populares sólo cuenten con una minoría concejil y ante una oposición mayoritaria la gobernabilidad resulte bloqueada. Por el contrario, la enmienda comunista postula la mayoría corporativa como una garantía de operatividad, pues de este modo el alcalde cuenta con el apoyo suficiente para realizar su política municipal (96).

El artículo 196 de la Ley Orgánica Electoral dispone que la elección del alcalde debe realizarse en la misma sesión de constitución del ayuntamiento, de acuerdo con el siguiente procedimiento: a) Pueden ser candidatos todos los concejales que encabecen sus correspondientes listas. b) Si alguno de ellos obtiene la mayoría absoluta de los votos de los concejales es proclamado electo. c) Si ninguno de ellos obtiene dicha mayoría es proclamado alcalde el concejal que encabece la lista que haya obtenido mayor número de votos populares en el correspondiente municipio. En caso de empate se resolverá por sorteo.

Junto a este régimen general, este mismo fragmento legal excepcionaliza, en coherencia con la representación mayoritaria

(96) El Proyecto de Ley de Elecciones Locales se publica en el Boletín Oficial de las Cortes, Congreso de los Diputados, núm. 43, de 4 de enero de 1978. El debate de la elección del alcalde se encuentra recogida en el Diario de Sesiones del Congreso de los Diputados, 1978, núm. 29, sesión plenaria de los días 9 y 10 de marzo de 1978, pp. 1113-1131. La enmienda comunista de la elección del alcalde obtuvo 303 votos a favor de los 312 emitidos, tres en contra y cinco abstenciones 
establecida, para los municipios comprendidos entre 100 y 250 habitantes este otro procedimiento: a) Pueden ser candidatos a alcalde todos los concejales. b) Si alguno de los candidatos obtiene la mayoría absoluta de los votos de los concejales es proclamado electo. c) Si ninguno obtuviere dicha mayoría, será proclamado alcalde el concejal que hubiere obtenido más votos populares en las elecciones de concejales. Obviamente, aunque la Ley no menciona el supuesto de empate de votos populares, hay que interpretar que la solución del sorteo es también aplicable a este procedimiento excepcional.

Para los municipios que funcionan en régimen de concejo abierto el legislador ha sido extremadamente parco en su regulación: Los electores eligen directamente al alcalde por sistema mayoritario e impone a las Juntas Electorales Provinciales la adopción de las resoluciones necesarias para dar cumplimiento a esta lacónica normativa (97).

El sistema de elección del alcalde del régimen vigente es una innovación en la historia del régimen municipal español. La Constitución de 1978, coherente con lo establecido en la Ley de Elecciones Locales, establece que «los alcaldes serán elegidos por los concejales o por los vecinos» (98). La legislación vigente ha optado por la elección concejil del alcalde, aunque con tales condicionamientos que en rigor es un procedimiento híbrido vecinoconcejil el que ha acabado estableciéndose, sin precedente alguno en nuestra historia municipal.

Desde una legitimación democrática, el modelo legislado se distancia de! presidencialista o alcalde elegido directamente por los electores del municipio, como así se estableció en 1812 y 1856. y se posibilita alternativamente en 1924 y 1936.

Pero no puede identificarse de modo absoluto la regulación actual con la de 1870, 1877 y con la alternativa de 1924 y 1936. Rigurosamente el modelo actual es original entre los establecidos en nuestra historia y presumible que también lo sea en el laboratorio del Derecho local occidental.

Nuestros constituyentes optaron por la adaptación al Gobierno municipal de la organización parlamentaria, pero la superior legitimación popular por la elección directa influyó y alteró el tradicional y normal modelo de elección concejil exclusiva del alcalde. Partiendo del sistema de candidatura de lista, los partidos mayoritarios proyectaban que el alcalde sería el cabeza de lista más votada electoralmente. El pueblo, pues, no sólo conocía a los futuros

(97) Ley Orgánica del Régimen Electoral General de 1985, arts. 179, 2 y 200.

(98) Constitución española, art. 140. 
concejales, sino también al alcalde. Con esta fórmula, además, las alcaldías serían para los partidos mayoritarios, mientras que los minoritarios no sólo no obtendrían éstas, sino que se verían alejados también de las Comisiones de gobierno de los ayuntamientos y, en general, de cualquier concejalía. Desde la ratio del modelo organizativo parlamentario adoptado y adaptado a la institución municipal, el problema funcional había de presentarse de modo inevitable en el supuesto de un alcalde electoralmente mayoritario, pero corporativamente minoritario, dada la presencia de varios partidos en el ayuntamiento. ¿Cómo se iba a legislar este presumible enfrentamiento y consiguiente bloqueo de un presidente del ayuntamiento con insuficiente apoyatura concejil para conseguir los votos necesarios para sacar adelante su política municipal? La solución estaba en que fuesen los concejales quienes eligiesen por mayoría, de entre los cabezas de lista, al alcalde, y así éste dispondría del apoyo suficiente y estable para gobernar. Los constituyentes sustituyeron la elección directa por la indirecta en razón de la racionalidad funcional, y los partidos pequeños adquirían importancia en la medida que sus votos serían, en muchos casos, necesarios para la elección de un alcalde. Como contrapartida exigirán su participación en el Gobierno municipal... y sobre todo justificaban su presencia en el ayuntamiento, e incluso su propia existencia (99).

En los municipios de 100 a 250 habitantes, dada la inexistencia de candidaturas de lista preceptivamente completas, la elección de alcaide se realiza por y entre los concejales. Sólo en el supuesto de que ningún concejal consiga la mayoría absoluta, será alcalde el candidato más votado popularmente, en coherencia con el sistema general en el que el cabeza de la lista más votada será el futuro presidente de la corporación si no se produce la mayoría absoluta concejil.

Se ha rechazado el modelo presidencialista de alcalde elegido directa y separadamente por los electores del municipio, pero el legislador, no desconociendo la coyuntural elección popular directa en nuestra historia municipal y, sobre todo, el arraigado y mayoritario deseo electivo popular de elegir a su propio alcalde, ha posibilitado legal y sobre todo realmente que los vecinos «elijan» a su alcalde. En el supuesto de una votación mayoritaria popular suficiente para proporcionar una mayoría concejil absoluta, el futuro alcalde no necesita apoyo de ningún otro grupo político y su elección por los concejales de su lista debe ser un acto formal. Si no hay mayoría absoluta concejil, el cabeza de lista más votada es

(99) Véase MARTin MATEO. R.: «El gobierno municipal», Revista de Estudios de la Administración Local y Autonómica, núm. 127, 1985, pp. 421-422. 
de modo automático proclamado alcalde. $\mathrm{Y}$, finalmente, salvo el supuesto excepcional de la renuncia, los vecinos reconocen a sus candidatos a-la alcaldía en las personas primeras de las listas electorales.

En los municipios que funcionan en Concejo Abierto, careciendo de concejales en razón de su democracia directa, los electores elijen de modo directo al alcalde por sistema mayoritario. Lamentablemente el legislador, simple y lacónico, ha remitido a las Juntas electorales provinciales la adopción de resoluciones necesarias para dar cumplimiento a las bases electorales establecidas: elección directa y representación mayoritaria. Ante la desconsideración legislativa por este régimen de democracia directa, los autores han puesto de manifiesto este vacío legal y su hipotética regulación por las costumbres y usos del lugar. Desconocemos jurisprudencia alguna sobre la elección del alcalde de los municipios en régimen de Concejo Abierto y es presumible que el procedimiento se limite a la presentación de candidaturas individuales y a la proclamación como alcalde del candidato con mayoría de votos.

El legislador no ha olvidado la elección de un nuevo alcalde por vacancia de la alcaldía. El artículo 198 de la Ley Electoral remite al procedimiento electivo general y considera primero de la lista al siguiente de la misma, aunque flexibiliza el procedimiento $y$, respetando la libertad concejil, posibilita la renuncia y la transmisión sucesiva de este derecho.

\subsection{Cese}

La referencia a las causas normales del cese del alcalde en el régimen actual excepcionaliza el criterio del tema en razón de su vigencia, aunque en coherencia con los criterios determinantes del estudio no se abundará en este extremo.

La legislación vigente impone la distinción entre las causas de cese o pérdida de la condición de concejal y del alcalde, aunque teniendo, salvo en el supuesto del Concejo Abierto, este último siempre el carácter concejil su cese como tal lleva aparejada la de alcalde.

La Ley Electoral de 1985, a efectos sustitutorios, hace referencia a los supuestos de incompatibilidad $y / 0$ inelegibilidad sobrevenida, fallecimiento, incapacidad, renuncia, expiración del mandato de cuatro años e, incluso, al supuesto disolutorio de un ayuntamiento por el Gobierno de la nación. Ante el silencio de la Ley Reguladora de las Bases del Régimen Local de este extremo, el Reglamento de Organización, Funcionamiento y Régimen Jurídico de las Corporaciones Locales, de 28 de noviembre de 1986 , establece el siguiente listado de causas determinantes de la pérdida 
de condición de concejal en su artículo 9: 1. Por decisión judicial firme, que anule la elección o proclamación. 2. Por fallecimiento o incapacitación, declarada ésta por decisión judicial firme. 3. Por extinción del mandato, al expirar el plazo, sin perjuicio de que continúe en sus funciones solamente para la administración ordinaria hasta la toma de posesión de sus sucesores. 4. Por renuncia, que deberá hacerse efectiva por escrito ante el Pleno de la Corporación. 5. Por incompatibilidad, en los supuestos y condiciones establecidos en la legislación electoral. 6. Por pérdida de la nacionalidad española.

Las causas de pérdida de la condición de concejal lo son obviamente también de la alcaldía en cuanto su titular, salvo en el régimen de Concejo Abierto, es siempre un concejal. No obstante la jurisprudencia ha reconocido que la renuncia o la pérdida del cargo de alcalde no conlleva la de concejal (100) y posteriormente el Reglamento de Organización, Funcionamiento y Régimen Jurídico de las Entidades Locales la ha positivado de modo expreso (101).

\subsection{La destitución-elección del alcalde a través de la moción de censura}

La Ley de Elecciones Locales de 1978 no regulaba la moción de censura del alcalde, pero la Ley Orgánica del Régimen Electoral General de 1985 la incorpora en su articulado. Hay una intervención jurisprudencial merecedora de una referencia especial.

El mencionado texto de 1978, hoy derogado por el de 1985, regulaba sin embargo la moción de censura del presidente de la diputación provincial en el artículo 34.3: «El Presidente podrá ser destituido de su cargo por acuerdo de la Corporación, adoptado por las dos tercertas partes del número de diputados." La existencia de este mecanismo destitutorio en la representatividad provincial nos fuerza especialmente a alinearnos en la afirmación de Cosculluela de que «la moción de censura municipal no estaba intencionadamente prevista en la Ley de Elecciones Locales" (102), incluso, como así lo ha recordado Rebollo Puig (103), las enmiendas dirigidas a institucionalizar esta destitución del alcalde fueron rechazadas en el

(100) Sentencia de la Audiencia Territorial de Barcelona, Sala Segunda de lo ContenciosoAdministrativo, de 22 de julio de 1981 . Sentencia de la Audiencia Territorial de Albacete de 24 de diciembre de 1981

(101) Reglamento de Organización. Funcionamiento y Régimen Jurídico de las Entidades Locales de 28 de noviembre de 1986, art. 40.4

(102) COSCIJluela L.: «Organización y Régimen jurídico de las Entidades Locales. La función pública local», en Organización Territorial del Estado. Administración Local, vol. I, Instituto de Estudios Fiscales, Madrid, 1985, p. 133

(103) REBOLlo PUIG, M.: "La moción de censura en la Administración Local», Revista de Estudios de la Administración Local y Autonómica, núm. 227, 1985, p. 471 
debate parlamentario de la Ley. El legislador no quiso consiguientemente institucionalizar este mecanismo destitutorio en el ámbito municipal.

El cese de los alcaldes y concejales por expulsión de su partido político, en virtud del artículo 11.7, forzó al Tribunal Constitucional a distinguir entre ambos cargos y la propia coherencia de su razonamiento jurídico condujo a amparar el cese concejil pero no el del alcalde, en virtud de que sólo podía cesar quien elegía y mientras a los concejales lo hacía el electorado popular al alcalde lo nombraban los propios concejales. Consiguientemente, la destitución de aquél por el partido político carecía de protección constitucional. La fundamentación del Alto Tribunal puede ser contestada con el supuesto previsto en el mismo artículo 28.3.c, pues según este fragmento, cuando ningún candidato obtuviera la mayoría absoluta de los votos de los concejales, será proclamado alcalde el concejal primero de la lista que hubiera obtenido más votos en el correspondiente municipio. Como es obvio y así lo ha destacado Luis Cosculluela, en este supuesto, y aunque en vía subsidiaria, el alcalde es elegido directamente por los votos de los vecinos (104). Pero además y a sensu contrario, ¿hubiese amparado el Tribunal Constitucional a un concejal destituido por los vecinos? Presumiblemente ni siquiera hubiera sido admitido el recurso... y desde luego es muy aventurado esperar que los tribunales contencioso-administrativos hubiesen fallado a favor de esta destitución por no estar previsto este mecanismo destitutorio en la legislación vigente.

La desestimación del amparo constitucional del cargo de alcalde de la sentencia de 4 de febrero de 1983 se convierte en una invitación práctica a los tribunales para que decidan sobre las mociones de censura. El Tribunal Supremo, en Sentencia de 14 de julio de 1983, viene en definitiva a aceptar la destitución política del alcalde -falta de confianza concejil- y a introducir praeter legem la moción de censura en el sistema jurídico español (105). El alcalde destituido recurre en amparo al Tribunal Constitucional, para quien "la cuestión puede ser considerada como una laguna legal que el juzgador debe colmar mediante una interpretación sistemática del ordenamiento jurídico y un recurso a los principios generales», y coherente con su propia jurisprudencia inadmite el recurso de amparo por Auto número 6 de 11 de enero de 1984. Una reiterada jurisprudencia del Tribunal Supremo acaba consolidando tanto la moción de censura como el principio de contrarius actus. Según

(104) Cosculluela L.: "Organización...», ob. cit., p. 133.

(105) Un comentario jurisprudencial de la sentencia de 14 de julio de 1983 se encuentra en RODRíguez MORO, N.: «El alcalde puede ser destituido por los concejales», Revista de Estudios de la Vida Local, núm. 224, 1984, pp. 549-553 
éste, no es necesaria la mayoría de dos tercios, como así está establecido expresamente para la destitución del presidente de la Diputación, sino la mayoría absoluta de los votos de los concejales (106). La realidad funcional, en este caso disfuncional, de los ayuntamientos demuestra rápidamente que, como ya lo señalara Sánchez Blanco (107), la inexistencia de regulación jurídica del voto de censura de los alcaldes era una laguna real y que, además de la responsabilidad civil y penal de éstos, la políca había de establecerse, como fórmula de operatividad y funcionalidad, frente a la de bloqueo que suponía la permanencia en la presidencia de un alcalde que carecía de la confianza concejil suficiente para poder gobernar con eficacia debida el municipio (108).

Así, pues, desde la sentencia del Tribunal Constitucional de 4 de febrero de 1983, las sentencias del Tribunal Supremo como de las Audiencias Territoriales comienzan a admitir la moción de censura constructiva; superan la incitación analógica de la exigencia de la mayoría de dos tercios, establecida para el presidente de la diputación, por la interpretación lógica de la mayoría absoluta en virtud del principio de contrarius actus; admiten la renuncia voluntaria de todo concejal que no quiera ser alcalde..., pues a nadie se le puede obligar a asumir una función para la que no se presentó; precisan que la mayoría absoluta de nueve concejales es cinco y consiguientemente resuelven este problema para todos los supuestos de número impar; obligan a convocar al alcalde la sesión para proceder a su propia moción de censura; e incluso posibilitan que si éste ha dejado la alcaldía para desempeñar otro cargo incompatible, pueda de nuevo volver a ocuparla si los demás concejales de la lista renuncian a su derecho (109).

El alcalde puede ser destituido de su cargo durante moción de censura adoptada por la mayoría absoluta del número legal de concejales. Esta ha de ser suscrita al menos por la tercera parte de los concejales y debe incluir el nombre del candidato propuesto para alcalde, quien quedará proclamado como tal en caso de

(106) Sentencias del Tribunal Supremo de 10 de octubre de 1984 (rep. de Aranzadi núm. 4.952), de 27 de marzo de 1985 (Aranzadı núm. 1.494), de 17 de diciembre de 1985 (Aranzadi núm. 6.278) y auto de 23 de junio de 1985 (Aranzadi núm. 3.876).

(107) SÁNCHEZ BLANCO, A.: "El control de la actividad de los presidentes de las Corporaciones Locales:, Revista de estudios de la vida local núm. 215, 1982, p. 464.

(108) SANTOLAYA se ha ocupado de la moción de censura con detenimiento especial en los efectos sustanciales y procedimentales de la Disposición transitoria tercera de la Ley Orgánica 5/1985. SANTOLAYA MACHETTI. P.: «Nota en torno a la posibilidad de cese de los alcaldes mediante la aprobación de una moción de censura (Comentario a cuatro recientes decisiones judiciales)», Revista de Administración Pública, núm. 108, 1985, pp. 225-267.

(109) Sentencias del Tribunal Supremo, Sala Tercera, de 14 de julio de 1983, de 27 de marzo de 1984, de 10 dé octubre del mismo año, de 23 de junio y 17 de diciembre de 1985 . Sentencia de la Audiencia de Burgos de 17 de mayo de 1979. Sentencia de la Audiencia Territorial de Albacete de 20 de diciembre de 1984. 
prosperar la moción. Ningún concejal puede suscribir durante su mandato más de una moción de censura. A los efectos previstos en el presente artículo todos los concejales pueden ser candidatos (110). Los principios de liderazgo, eficacia, libertad y limitación de una sola moción de censura mediante el mandato concejil impregnan esta fórmula constitucionalizada por el artículo 113 para el Gobierno de la nación, adoptada y obviamente adaptada a las Entidades territoriales del Estado español.

El legislador no ha regulado la moción de censura en los municipios de democracia directa, pero una interpretación sistemática la posibilita y la equiparación procedimental de los electores con los concejales, a efectos de la iniciativa y de los quórum exigidos para la votación, la factibiliza.

\subsection{La disolución gubernativa del ayuntamiento como cese anormal del alcalde}

La constitucionalización del Estado de las autonomías y del carácter electivo de las Corporaciones municipales fundamenta presumir la inexistencia de fragmento jurídico alguno que faculte al Gobierno para suspender, destituir o disolver a los elegidos o a los ayuntamientos repectivos; sin embargo, esta intervención se encuentra positivada en su grado máximo en el artículo 61 de la Ley Reguladora de las Bases del Régimen Local de 1985 y cuyo tenor literal es el siguiente: «1. El Consejo de Ministros, a iniciativa propia y con conocimiento del Consejo de Gobierno de la Comunidad Autónoma correspondiente o a solicitud de éste $y$, en todo caso, previo acuerdo favorable del Senado, podrá proceder, mediante Real Decreto, a la disolución de los órganos de las Corporaciones Locales en el supuesto de gestión gravemente dañosa para los intereses generales que supongan el incumplimiento de sus obligaciones constitucionales. 2. Acordada la disolución, será de aplicación la legislación electoral general en relación a la convocatoria de elecciones parciales y a la provisional administración ordinaria de la Corporación.»

La anomalía es la primera de las calificaciones a que este fragmento se hace merecedor. La disolución de una Corporación municipal es la medida más grave con que el Gobierno puede intervenir la representatividad municipal. La multa, el apercibimiento, la suspensión y la destitución de sus miembros han sido las manifestaciones escalonadas de la intensidad dependentística municipal del Gobierno de la nación y, por consiguiente, de su menor representatividad popular, descentralización o autonomía.

(110) Ley Orgánica del Régimen Electoral General de 19 de junio de 1985, art. 197

REVISTA DE ESTUDIOS.-6 
Sólo excepcionalmente los textos locales antidemocráticos se han atrevido a institucionalizar la disolución y éstos, en nuestra historia, han sido los de 1835,1840 y 1845 . El de 1856, aun elaborado en un período político inestable, sólo se atreve a facultar al Gobierno para presentar un proyecto disolutorio a las Cortes y que sean éstas las que mediante ley puedan únicamente decidir tan excepcional medida. El estatuto municipal, en su representatividad de papel, sólo se atrevió a suspender al alcalde en sus funciones de delegado gubernamental pero no en el de su cargo de máxima autoridad popular. La Ley de 1935 facultaba al Gobierno la suspensión del alcalde y el nombramiento interino como tal de un concejal, pero constreñía esta facultad al supuesto de que la provincia, a la que perteneciera el término municipal respectivo, se encontrara en alguno de los tres estados de prevención, alarma o guerra. Los constituyentes gaditanos no admitieron estas interferencias gubernamentales en la representatividad municipal.

Ante esta facultad intervencionista anómala $y$ desde luego contradictoria con la electividad popular y autonomía constitucionalizada se formula la siguiente pregunta: ¿Cómo explicar este intervencionismo disolutorio de la representatividad democrática municipal? Presumiblemente las causas se encuentran en la sentencia del Tribunal Constitucional de 2 de febrero de 1981 y en la situación política y social anormalizada del País Vasco.

El artículo 422 de la Ley del Régimen Local franquista de 1955 posibilitaba de este modo la facultad disolutoria gubernamental: «El Consejo de Ministros, a propuesta del de la Gobernación y previa audiencia de las Entidades interesadas e informe del Servicio de Inspección y Asesoramiento, podrá decretar la disolución de los Ayuntamientos y Diputaciones Provinciales cuando su gestión resulte gravemente dañosa para los intereses generales o los de la respectiva Entidad local.» Ante este fragmento, el Tribunal Constitucional solamente declara inconstitucional la facultad disolutoria gubernamental cuando la gestión resulte gravemente dañosa para «los intereses de la respectiva Entidad local». El fundamento jurídico número 10 razona la constitucionalidad de la disolución en el supuesto de gestión gravemente dañosa para «los intereses generales» pues, según el citado Tribunal, «el artículo 137 sólo garantiza el carácter autónomo municipal para la gestión de sus respectivos intereses. En cambio no se garantiza por la Constitución-como es obvio- para incidir de forma negativa sobre los intereses generales de la nación o en otros intereses generales distintos de los propios de la entidad, por lo que en estos supuestos la potestad del Estado no se puede declarar contraria a la Constitución, máxime cuando este principio de limitación de la autonomía se refleja de forma 
expresa en la propia Constitución -art. 155- en relación a las Comunidades Autónomas.»

El Partido Socialista que significativamente había recurrido a este precepto disolutorio franquista como inconstitucional, amparado ahora por la interpretación del Alto Tribunal, lo reproduce en esencia en el artículo 61 de la Ley 7/1985. Incoherente cambio, pues el legislador no estaba obligado a preceptuar de nuevo este indeseado intervencionismo en una Entidad local. No obstante, constitucionalizado expresamente por el Tribunal Constitucional y positivado después por el legislador resulta obligado razonar la discrepancia.

La sentencia de 2 de febrero de 1981 constitucionaliza la más grave tutela de oportunidad del Estado sobre los Entes locales en razón de uuna gestión gravemente dañosa para los intereses generales». El razonamiento es, en esencia, el mismo con que los moderados de 1840 y 1845 argumentaban la designación gubernativa de los alcaldes y, por consiguiente, su cese y la disolución de la Corporación local: en el municipio confluyen intereses particulares e intereses generales... y el alcalde y tenientes de alcalde, en la medida que eran ejecutores de las disposiciones del Gobierno, debían contar con su confianza... y de ahí la tutela sobre las personas -suspensión, cese y disolución- establecida en el supuesto de pérdida de la confianza política por mala gestión. Los conservadores de 1877 ya no fundamentan su menor intervencionismo en'el argumento capital de la confluencia de intereses, sino más bien en la acción unitaria administrativa estatal y, de ahí, que el poder central "pueda» nombrar y cesar a los alcaldes de los medianos y mayores municipios, pues los pequeños carecen de significación demográfica y política; pero, desde luego, no se atreven a legislar la disolución gubernativa de la Entidad local. EI Estatuto municipal de Calvo Sotelo, desde la coherencia jurídica democrática, sólo posibilita al Gobierno suspender al alcalde en sus funciones de delegado suyo no en el cargo de alcalde. Y la Ley municipal republicana de 1935 faculta la suspensión gubernativa del alcalde, pero sólo en el supuesto excepcional de que la provincia respectiva se encuentre en estado de prevención, alarma o guerra. •

La disolución gubernativa de la Entidad local suplanta a la voluntad popular que constitucionalmente es la única que puede elegir $-y$ cesar- a los ayuntamientos. El interés general, como criterio disolutorio, es arcaico y propio de otro sistema, pues en el Estado actual tiene su concreción jurídica en las respectivas competencias y es a éstas a las que hay que hacer referencia como exigencia de actuación jurídica. En el supuesto de competencias 
estatales delegadas municipalmente, el Gobierno central puede suspender tal delegación o su ejercicio pero no suspender o disolver la Corporación, pues para salvaguardar sus intereses de la gestión dañosa no necesita incluso una medida tan drástica como es ésta de la decapitación del municipio.

La teorización de un Estado de las Autonomías rechaza la tutela sobre las personas elegidas por la voluntad popular y su control jurídico debe corresponder a los jueces y magistrados de modo exclusivo. Sorprendentemente el Tribunal Constitucional al admitir esta tutela de oportunidad y legitimar la de legalidad, «versión no generosa de la Autonomia» para Martín Mateo (111), ha posibilitado su mantenimiento, esencialmente en los mismos extremos, en el artículo 61 de la Ley reguladora de las Bases de Régimen Local de 1985. ¿Ha podido influir la situación política anormal del País Vasco en la voluntad legislativa para institucionalizar este intervencionismo resolutorio? Presumiblemente, pero nuestro Estado de Derecho constitucionaliza también las respuestas juridicas excepcionales a situaciones especiales de grave anormalidad en el artículo $116 \mathrm{y}$, en consecuencia, es desde esta situación donde la procedencia de determinadas medidas intervencionistas del Gobierno central pueden ser explicadas y, en su caso, justificadas.

La exégesis del precepto postula una consideración material y otra procedimental. Por la primera hay que calificar este intervencionismo disolutorio de una tutela de legalidad sobre las personas; sin embargo, esta calificación debida al nuevo párrafo añadido por el texto de 1985 - «... que suponga el incumplimiento de sus obligaciones constitucionales»- es una legalidad especialmente genérica e indeterminada, pues si el Gobierno debe aducir el artículo constitucional incumplido también hay que señalar el alto grado de discrecionalidad de su apreciación y la falta de seguridad jurídica que, cual espada de Damocles, pende sobre cualquier Corporación al remitir sus causas disolutorias, nada más ni nada menos, que al texto constitucional. Concepto indeterminado calificador de otro de la misma naturaleza como es el interés general y que vienen ambos a descalificar tanto material como técnica la fórmula disolutoria legislada.

Procedimentalmente el Real Decreto disolutorio debe ir precedido de una iniciativa gubernamental, propia o solicitada por la Comunidad Autónoma correspondiente, conocimiento del Consejo de Gobierno de ésta, informe preceptivo no vinculante de la

(111) MARTin MATEO, R.: «Autonomía y régimen local preconstitucional (Sentencia del Tribunal Constitucional de 2 de febrero de 1981)», Revista Española de Derecho Administrativo. número 29,1981, p. 371 . 
Comisión Nacional de Administración Local (112) y acuerdo favorable del Senado. No hay trámite de audiencia a la Corporación municipal afectada. Como es obvio, el Real Decreto disolutorio es recurrible en vía contencioso-administrativa por los titulares de los órganos disueltos tanto colectiva como individualmente. Dada la remisión en bloque a la Ley electoral de todas estas cuestiones de representatividad, el texto de régimen local adapta esta situación al supuesto de elecciones parciales y a la provisional administración ordinaria de la Corporación regulada en el artículo 183 de la Ley Orgánica del Régimen Electoral General. Anacrónico, antiautonómico y anormal, tanto material como procedimentalmente son calificativos que este fragmento merece en un ordenamiento jurídico como el actual.

\section{CONSIDERACIONES FINALES}

La elección y cese del alcalde reproduce en la organización municipal el modelo parlamentario constitucionalizado para las organizaciones territoriales estatal y autonómica. Según la ratio de este sistema, la jefatura de estos Gobiernos resulta de la elección de segundo grado de los diputados y de los concejales. El legislador ordinario, entre la opción constitucionalizada en el artículo 140 de alcalde elegido por los vecinos o por los concejales, ha optado por la de segundo grado propia de los regímenes parlamentarios. Esta calificación del alcalde como jefe del Gobierno municipal frente al alcalde presidencialista se manifiesta de modo contundente en la destitución -elección a través de la moción de censura. La mayoría concejil es quien destituye y elige al alcalde-. Luis Cosculluela se ha referido de modo expreso a esta analogía de la moción de censura constructiva del alcalde con la constitucionalizada del presidente del Gobierno... «en una manifestación más de la indiscriminadora aplicación de técnicas parlamentarias a las relaciones entre órganos de las Corporaciones Locales» (113). Suele ser práctica generalizada en los Estados de Occidente que los gobiernos locales reproduzcan, adoptándolos y adaptándolos, el modelo organizativo de Gobierno central.

Esta adaptación al Gobierno municipal del modelo parlamentario ofrece, en el caso español, unas características que vienen a definirle y peculiarizarle. Responden a las exigencias de los principios de democracia, eficacia y libertad.

(112) Artículo 118 de la Ley Reguladora de las Bases del Régimen Local de 2 de abril de 1985 .

(113) Cosculluela L.: "Las elecciones locales», en la obra dirigida por S. MUÑoz MACHADO: Tratado de Derecho municipal, I. Civitas, Madrid, 1988, p. 724. 
La elección de segundo grado del presidente del Gobierno no es trasladable miméticamente a la del alcalde, pues las diferencias son bien acusadas y están impregnadas de una máyor democraticidad. Los supuestos electivos regulados en el artículo 196 de la Ley Orgánica del Régimen Electoral General ofrecen notables diferencias con la elección pura y simple de segundo grado. En primer lugar, los candidatos a la alcaldía se limitan a los concejales primeros de las listas electorales $y$, por consiguiente, el electorado conoce y "vota» a su futuro alcalde, pues si una lista obtiene la mayoría absoluta de los sufragios populares obtendrá también la mayoría absoluta concejil y la elección del cabeza se convertirá en un acto corporativo meramente formal. Si no se produce este resultado, la elección es concejil, pero los ediles deben limitarse sólo a los cabezas de las listas electorales. En definitiva, este procedimiento se convierte en un sucedáneo de la ausencia de una mayoría electoral suficiente en el municipio capaz de proporcionar la mayoría concejil necesaria. Finalmente, de no darse ninguno de estos dos supuestos de mayoría corporativa absoluta, el electorado es quien ha determinado que el cabeza de la lista más votada sea el alcalde. Toda vez que la mayoría absoluta necesaria para gobernar no se ha conseguido, se impone la voluntad popular mayoritaria simple.

Junto a esta superación democrática de la elección pura de segundo grado, el principio de la eficacia impregna la regulación electiva del alcalde. $Y$ este principio ha sido quien, en definitiva, ha empujado a la jurisprudencia, en una interpretación sistemática del sistema, a admitir en el ámbito municipal la moción de censura constructiva del alcalde. Y es que sin una mayoría estable concejil el gobierno del municipio se imposibilita o, cuanto menos, se dificulta. Para que esto no suceda, el legislador, y con antelación la doctrina jurisprudencial, ha positivado que el alcalde sea quien tenga la mayoría para gobernar con mayor eficacia el municipio. La moción de censura constructiva es un instrumento garantizador de la funcionalidad del Gobierno municipal y la obligada inclusión del candidato a la alcaldía pretende impedir que no se produzca el vacío de poder (114). Incluso, en virtud del principio mismo de la eficacia, en esta elección-sustitución del alcalde determinada por una crisis de la mayoría, el legislador dispone que cualquier concejal pueda ser propuesto como candidato en la mencionada moción, pues la finalidad no es otra que la recuperación de la nueva mayoría

(114) La sentencia de 21 de abril de 1987. Sala Quinta del Tribunal Supremo (Aranzadi, núm. 2.980), ha reconocido de modo expreso la ausencia de un nombre de alcalde como defecto material suficiente para no tramitar el procedimiento de la moción de censura. 
para salir de la crisis, y de ahí la conveniencia de no establecer requisitos obstaculizadores de este objetivo.

Desde la racionalidad del sistema parlamentario -teóricamente, sin embargo, el modelo presidencialista nos parece más democrático y eficaz-, la legislación de la elección y cese del alcalde es aceptable y defendible. Lo es, como ya se ha indicado, por su democraticidad y su eficacia; pero, también porque frente a la representación del partido político, el Tribunal Constitucional -otra gran aportación jurisprudencial junto a la moción de censura constructiva- ha proclamado la representación popular de los elegidos. El concejal no puede ser cesado por el respectivo partido político, pues el Tribunal Constitucional, al inconstitucionalizar el artículo 11.7 de la Ley de Elecciones Locales de 1978, con su histórico fallo de 4 de febrero de 1983, da al artículo 23 de la Constitución toda su dimensión democrática: son los ciudadanos quienes tienen el derecho a participar en los asuntos públicos... y no los partidos políticos. Los representantes lo son de los ciudadanos y no de los partidos y sólo aquellos que los eligen pueden cesarlos. En una interpretación sistemática, el derecho que tienen los ciudadanos para acceder a los cargos públicos lo tienen de igual modo para mantenerse en ellos (115).

La independencia en el cargo del concejil de su respectivo partido político conlleva su absoluta libertad de voto y la posibilidad del «transfuguismo» político está amparado jurídicamente. E! Tribunal Supremo ya ha tenido ocasión de manifestarse al respecto ante una moción de censura contra un alcalde y su consiguiente destitución del cargo, «gracias a la deserción de los concejales, que habiendo sido elegidos dentro de las listas de un determinado partido o coalición, votaron en la ocasión de autos con los concejales hasta entonces opositores en el ayuntamiento, pasando con ello el grupo mayoritario a minoritario, y viceversa» (116).

La Sentencia citada, en su fundamento segundo, considera que esta alegación de transfuguismo es una cuestión ética y moral, pero carece de solución jurídica. $Y$ en el siguiente fundamanto se refiere a esta conducta del concejal que vota contrariamente a su propio partido en los siguientes términos: «El problema a que nos estamos refiriendo es más complejo de lo que aparece a primera vista, porque está en juego el concepto de representación política -reflejada en el de los concejales antes aludidos-; el de si la representación lleva inherente un mandato del cuerpo electoral; el

(115) Véase MARTíNEZ MARíN. A.: La representatividad municipal española. Historia legislativa y régimen vigente, Universidad de Murcia, Murcia, 1989, pp. 180 y ss.

(116) Sentencia del Tribunal Supremo, Sala Cuarta, de 7 de abril de 1988, Aranzadi, número 2.662 . 
de la autonomía de los cargos elegidos, y el de su vinculación con el grupo político en el que figuraron en la convocatoria electoral. Temas objeto de permanente análisis y controversias, entre las que figura la de la fidelidad del cargo elegido al partido, y la de si ésta debe primar sobre la conciencia del representante o al revés; sin faltar en este terreno las críticas a la férrea disciplina que los partidos tratan de imponer a todos sus miembros, a costa de su personalidad individual y su sentido de la responsabilidad». Lamentablemente el fallo del Alto Tribunal se limita al simple enunciado del problema y remite su solución al mundo de la ética y de la moral; pero, en nuestra opinión, hay también respuestas jurídicas para este problema.

En primer lugar, el mandato dado a nuestros concejales no es en absoluto imperativo; contrariamente, el voto del elector como el del elegido, en todo momento, debe ser libre. Consiguientemente, ningún grupo o partido político puede quebrantar la libertad del voto del concejil. El artículo $5 .^{\circ}$ de la Ley Orgánica del Régimen Electoral General positiviza que «Nadie puede ser obligado o coaccionado bajo ningún pretexto en el ejercicio de su derecho de su sufragio ni a revelar su voto». La libertad de voto es individual y sólo será libre cuanto sea individual, sin coacciones y sin pérdida, en este caso, del mandato concejil.

La representatividad del concejal es del pueblo y no del partido político. El Tribunal Constitucional, de modo expreso, lo proclamó en su histórico fallo de 4 de febrero de 1983 al inconstitucionalizar la dependencia del concejal de su pertenencia al partido político respectivo. Si el artículo 11.7 de la Ley de Elecciones Locales de 1978 no hubiese sido inconstitucionaliżado el fenómeno del transfuguismo político no hubiese existido en la vida municipal española, pues quien no votara con el partido quedaría no sólo fuera del partido, sino también del Ayuntamiento. La decisión jurisprudencial, frente al fragmento paritocrático legislado, tuvo y tendrá un alcance democrático insospechado. Si los concejales debieran votar con su partido siempre y no con su conciencia, la oligarquía del partido acabaría imponiendo a los miles de sus concejales sus directrices sin posibilidad alguna de resistencia y discrepancia. La libertad de voto del concejal es un problema jurídico a la que se le ha dado una regulación jurídica: la libertad de voto sin coacción o pérdida del mandato representativo. Al legislar la libertad del voto concejil se positiviza, como es obvio, su libre y personal ejercicio. 